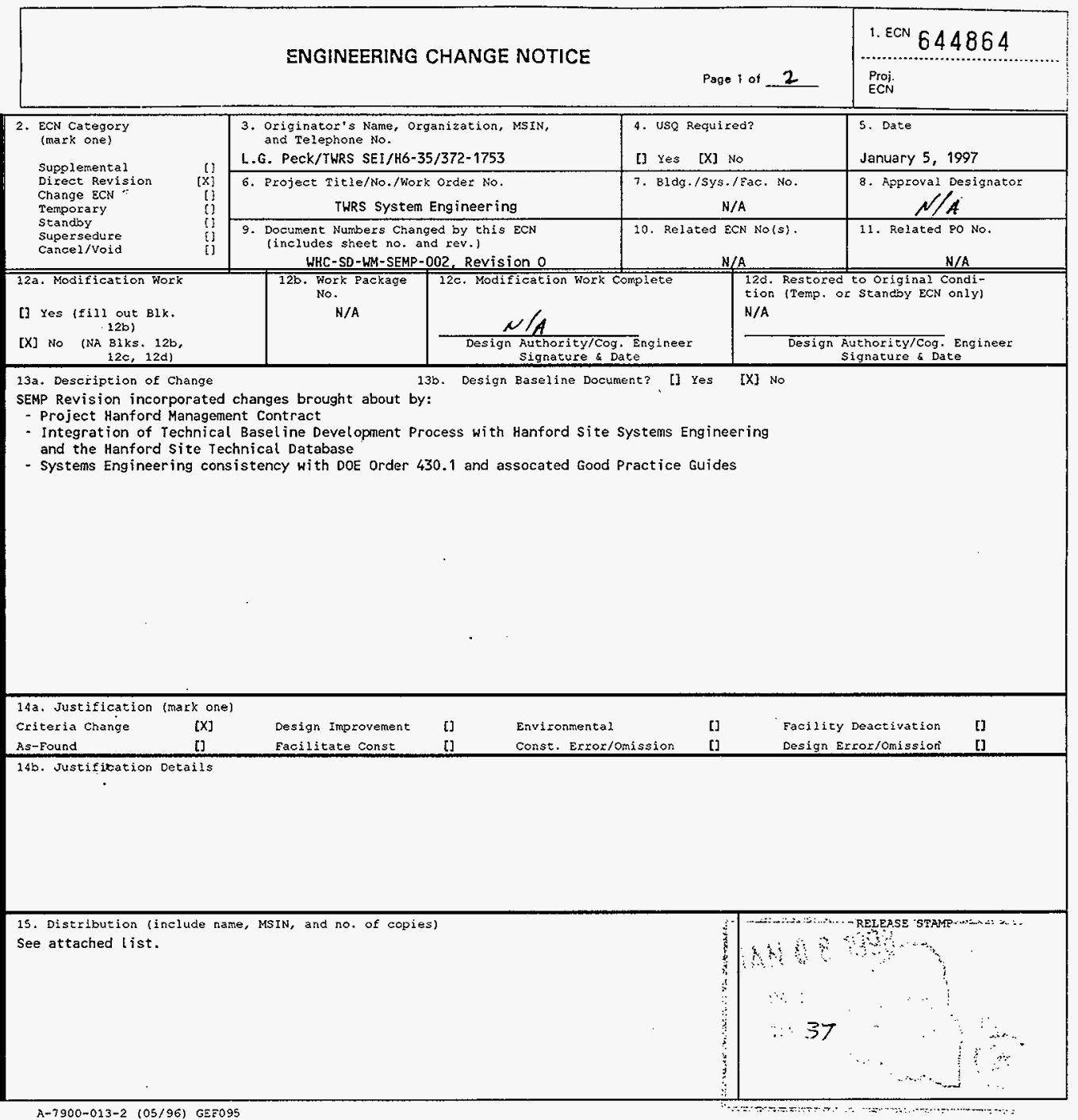




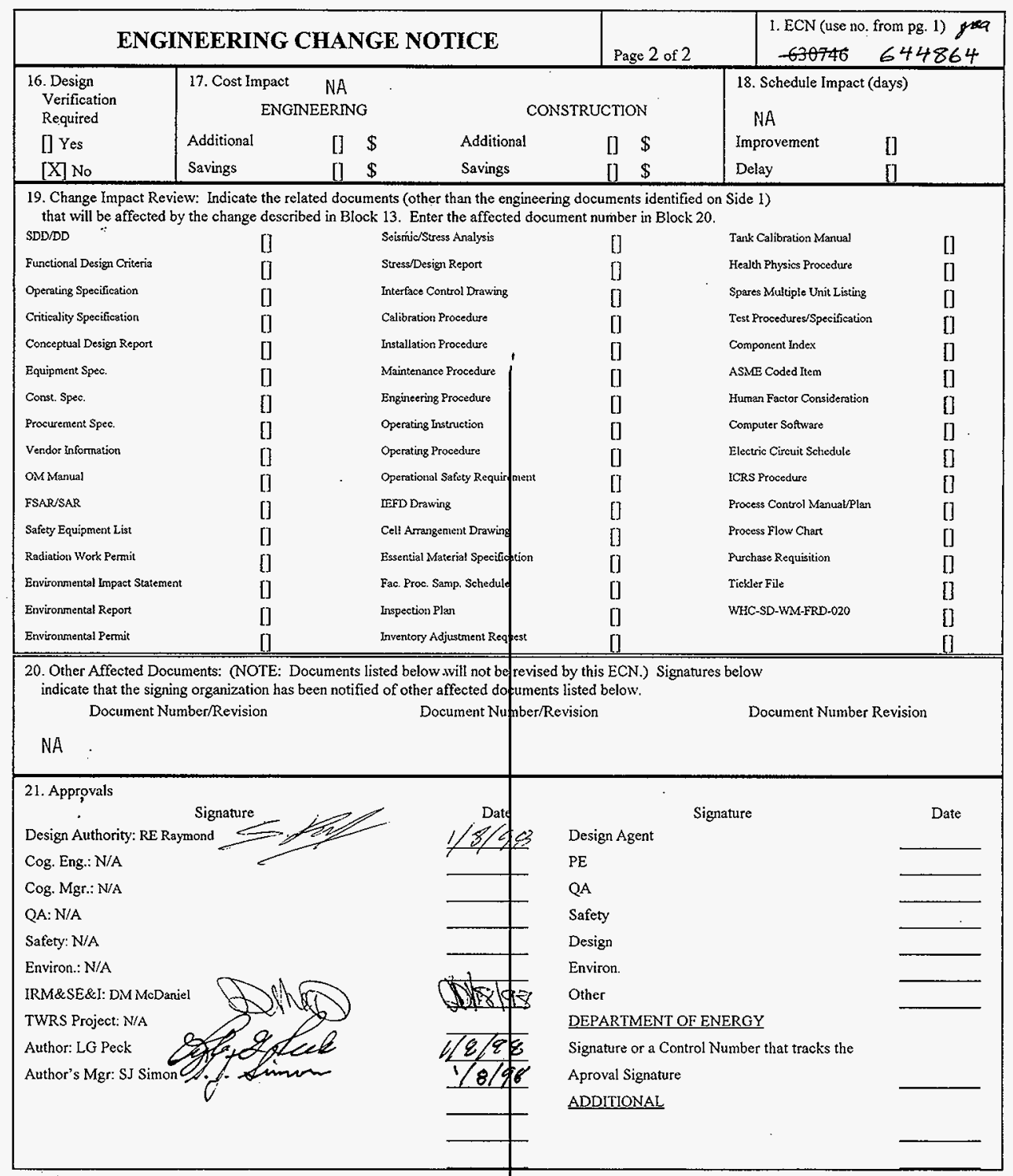




\section{Tank Waste Remediation System Systems Engineering Management Plan}

L.G. Peck

Lockheed Martin Hanford Company, Richland, WA 99352

U.S. Department of Energy Contract DE-AC06-96RL13200

EDT/ECN: 644864

Org Code: 76000

B\&R Code: EW3130010

UC: 2030

Charge Code: D215P

Total Pages: 7980

Key Words: TWRS, Systems Engineering

Abstract: This pian describes the Tank Waste Remediation System (TWRS) implementation of the U.S. Department of Energy (DOE) systems engineering policy provided in 97-MSD-193. It defines the products, process, organization, and procedures used by the TWRS Project to implement the policy.

TRADEMARK DISCLAIMER. Reference herein to any specific commercial product, process, or service by trade name, trademark, manufacturer, or otherwise, does not necessarily constitute or imply its endorsement, recommendation, or favoring by the United States Government or any agency thereof or its contractors or subcontractors.

Printed in the United States of America. To obtain copies of this document, contact: Document Control Services, P.0. Box 950, Mailstop H6-08, Richland WA 99352, Phone (509) 372-2420;
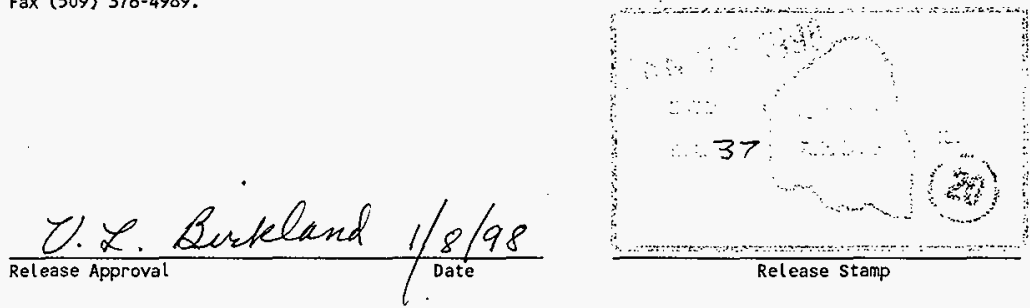

\section{Approved for Public Release}


RECORD OF REVISION

(1) Document Number

HNF-SD-WM-SEMP-

Page 1 002, REV 1

(2) Title

TANK WASTE REMEDIATION SYSTEM SYSTEMS ENGINEERING MANAGEMENT PLAN

CHANGE CONTROL RECORD

(3) Revision

0

$1 \%$ Revision per $\mathrm{ECN}-6974664864$ a
(4) Description of Change - Replace, Add, and Delete Pages

(7) Rev. 0, EDT \#612837 2/6/96
Authorized for Release

\begin{tabular}{l|l} 
(5) Cog. Engr. & (6) Cog. Mgr. Date
\end{tabular}

LG Peck

JD Thomson

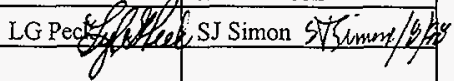




\section{Tank Waste Rẹmediation System System Engineering Management Plan}

L. G. Peck

Lockheed Martin Hanford Corporation

Date Published

January 1998

Prepared by Lockheed Martin Hanford Corporation Richland, Washington

Prepared for the U.S. Department of Energy

T- Fluor Daniel Hanford, Inc.

P.O. Box 1000

Richland, Washington

Hanford Management and Integration Contractor for the

U.S. Department of Energy under Contract DE-AC-0696-RL 13200 
HNF-SD-IVM-SEMP-002 Rev 1

This page intentionally left blank. 
HNF-SD-WM-SEMP-002 Rev 1

Document Title: Tank Waste Remediation System Systems Engineering Management Plan

Approved by:

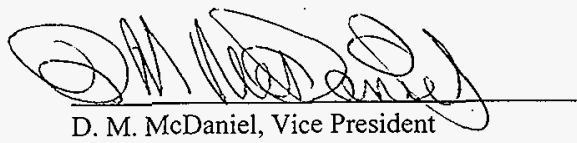

Information Resource Management Systems,

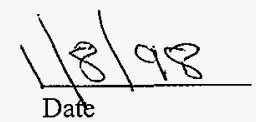

Engineering and Integration

Lockheed Martin Hanford Corporation 
HNF-SD-WM-SEMP-002 Rev I

This page intentionally left blank. 


\section{CONTENTS}

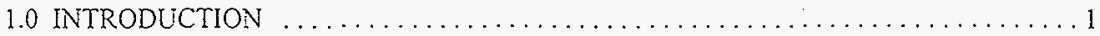

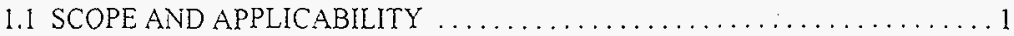

1.2 SYSTEMS ENGINEERING MANAGEMENT PLAN SUMMARY $\ldots \ldots \ldots \ldots 1$

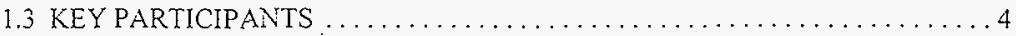

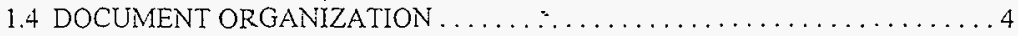

2.0 INTEGRATED BASELINE MANAGEMENT $\ldots \ldots \ldots \ldots \ldots \ldots \ldots \ldots \ldots \ldots \ldots \ldots \ldots \ldots \ldots$

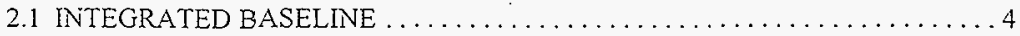

2.2 SYSTEMS ENGINEERING MANAGEMENT PLAN IMPLEMENTATION $\ldots 10$

2.2.1 Systems Engineering in Subcontracts $\ldots \ldots \ldots \ldots \ldots \ldots \ldots \ldots \ldots$

2.2.2 Systems Engineering Program Evaluation ................. 11

2.3 MANAGEMENT OF THE INTEGRATED BASELINE $\ldots \ldots \ldots \ldots \ldots \ldots \ldots 11$

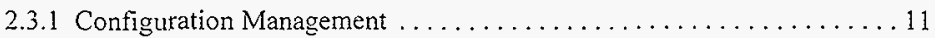

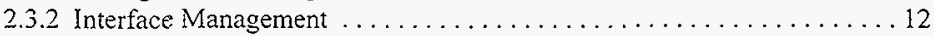

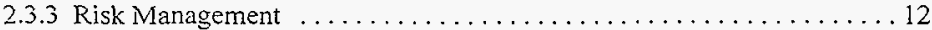

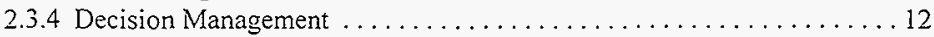

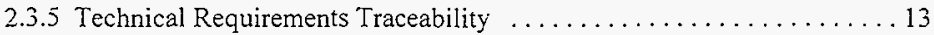

2.3 .6 Technical Reviews ............................. 13

2.3.7 Technical Performance Measurement .................... 15

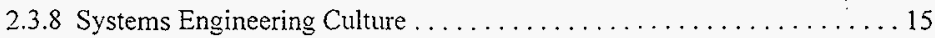

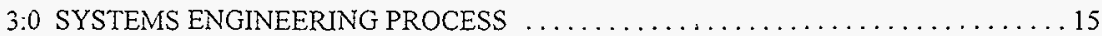

3.1 SYSTEMS ENGINEERING PROCESS OVERVIEW $\ldots \ldots \ldots \ldots \ldots \ldots 16$

3.2 SYSTEMS ENGINEERING PROCESS APPLICATION TO TANK WASTE

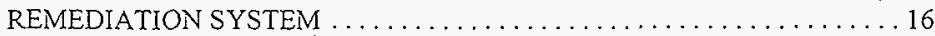

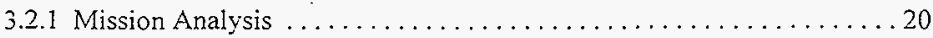

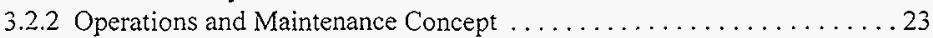

3.2.3 Functional Analysis . . . . . . . . . . . . . . . . . . . . . 23

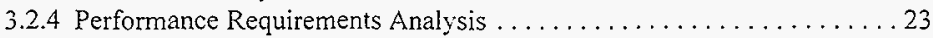

3.2.5 System Assessments/Evaluations . . . . . . . . . . . . . . . 24

3.2.6 Alternative Analysis and Selection (Synthesis) . . . . . . . . . . 24

3.2 .7 Requirements Allocation . . . . . . . . . . . . . . . . . . 25

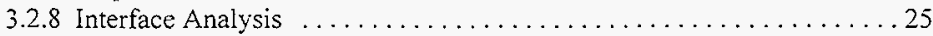

3.2 .9 Specialty Engineering Analysis and Integration $\ldots \ldots \ldots \ldots \ldots \ldots . \ldots \ldots$

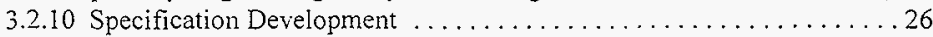

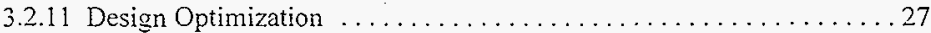

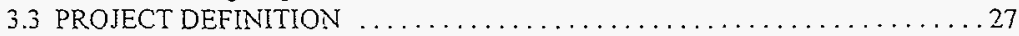

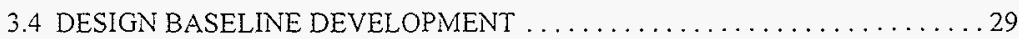

3.5 PHYSICAL SYSTEM TEST AND EVALUATION $\ldots \ldots \ldots \ldots \ldots \ldots \ldots \ldots$

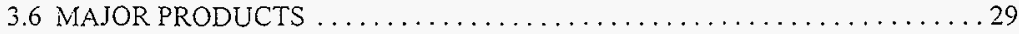

3.7 INTEGRATED LOGISTICS SUPPORT $\ldots \ldots \ldots \ldots \ldots \ldots \ldots \ldots \ldots \ldots \ldots \ldots \ldots \ldots$ 
HNF-SD-WM-SEMP-002 Rev 1

CONTENTS (Continued)

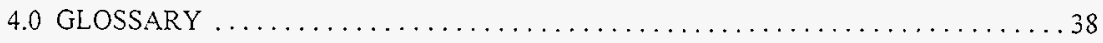

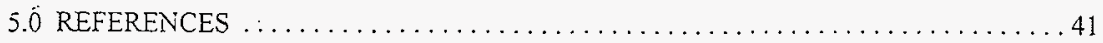

\section{APPENDIXES}

A GUIDANCE AND REQUIREMENTS TO DELIVERABLES CROSSWALK TWRS SYSTEM ENGINEERING MANAGEMENT PLAN

B COMPLIANCE MATRIX, SYSTEMS ENGINEERING MANAGEMENT PLAN TO TANK WASTE REMEDIATION SYSTEM U.S. DEPARTMENT OF ENERGY, RICHLAND OPERATIONS OFFICE POLICY ............. B-i 


\section{LIST OF FIGURES}

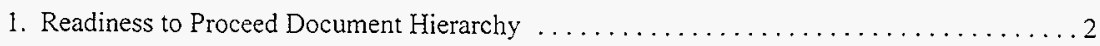

2. Tank Waste Remediation System Top-Level Document Relationships ............ 5

3. Tank Waste Remediation System Program Logic $\ldots \ldots \ldots \ldots \ldots \ldots \ldots \ldots \ldots$

4. Tank Waste Remediation System Technical Baseline . . . . . . . . . . . . . . 9

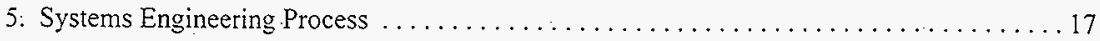

6. Tank Waste Remediation System Technical Baseline Development Strategy . . . . . . . . 20

7. Tank Waste Remediation System Systems Engineering Analysis Overview . . . . . . . . 22

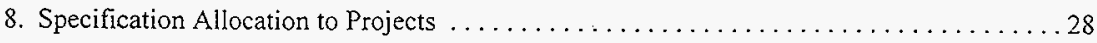

\section{LIST OF TABLES}

1: Tank Waste Remediation System Major Facilities by Phase Allocated to the Tank Waste

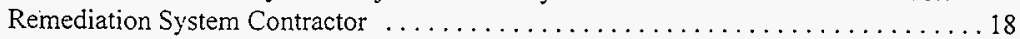

?

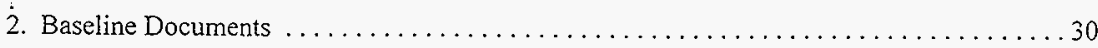




\section{LIST OF TERMS}

AGA

BIO

$\mathrm{CD}$

DOE

HLW

HSTD

ICD

LAW

MAR

O\&M

PHMC

RL

SEMP

SSC

TWRS

WBS

alternative generation and analysis

Basis for Interim Operation

Critical Decision

U.S. Department of Energy

high-level waste

Hanford Site Technical Database

Interface Control Document

low-activity waste

Mission Analysis Report

operations and maintenance

Project Hanford Management Contract

U.S. Department of Energy, Richland Operations Office

Systems Engineering Management Plan

structure, system, and component

Tank Waste Remediation System

work breakdown structure 


\section{TANK WASTE REMEDIATION SYSTEM SYSTEMS ENGINEERING MANAGEMENT PLAN}

\subsection{INTRODUCTION}

This Systems Engineering Management Plan (SEMP) describes the Tank Waste Remediation System (TWRS) implementation of the U.S. Department of Energy (DOE) systems engineering policy provided in 97-MSD-193, Tank Waste Remediation System Systems Engineering Management Policy (RL 1997). The SEMP defines the products, process, organization, and procedures used by the TWRS Project to implement the policy. The SEMP will be used as the basis for tailoring the systems engineering applications to the development of the physical systems and processes necessary to achieve the desired end states of the program. It is a living document that will be revised as necessary to reflect changes in systems engineering guidance as the program evolves.

The U.S. Department of Energy-Headquarters has issued program management guidance, DOE Order 430.1, Life Cycle Asset Management, and associated Good Practice Guides that include substantial systems engineering guidance. Although this order is not imposed by the Project Hanford Management Contract (PHMC) (RL 1996b), the TWRS Project will use this order to mold robust systems engineering efforts.

\subsection{SCOPE AND APPLICABILITY .}

$\because$

This SEMP applies to the TWRS Project maintenance and integration contractors. The SEMP focuses on the systematic development of the Technical Baseline to ensure a complete and traceable engineering design solution to meet the mission needs and requirements. It applies to the TWRS contractor and associated Project Hanford Management Contract (PHMC) subcontractors.

This revision of the SEMP is a part of evidence supporting Phase 1 Readiness to Proceed. The Readiness to Proceed document hierarchy is shown in Figure 1.

\subsection{SYSTEMS ENGINEERING MANAGEMENT PLAN SUMMARY}

This TWRS SEMP describes the implementation of systems engineering in the TWRS Project. This SEMP is a revision to capture modifications resulting primarily from three factors: the award of the PHMC (RL 1996b); the cancellation of DOE Order 4700.1, Project Management System, and subsequent establishment of DOE Order 430.1; and the development of 
HNF-SD-WM-SEMP-002 Rev 1

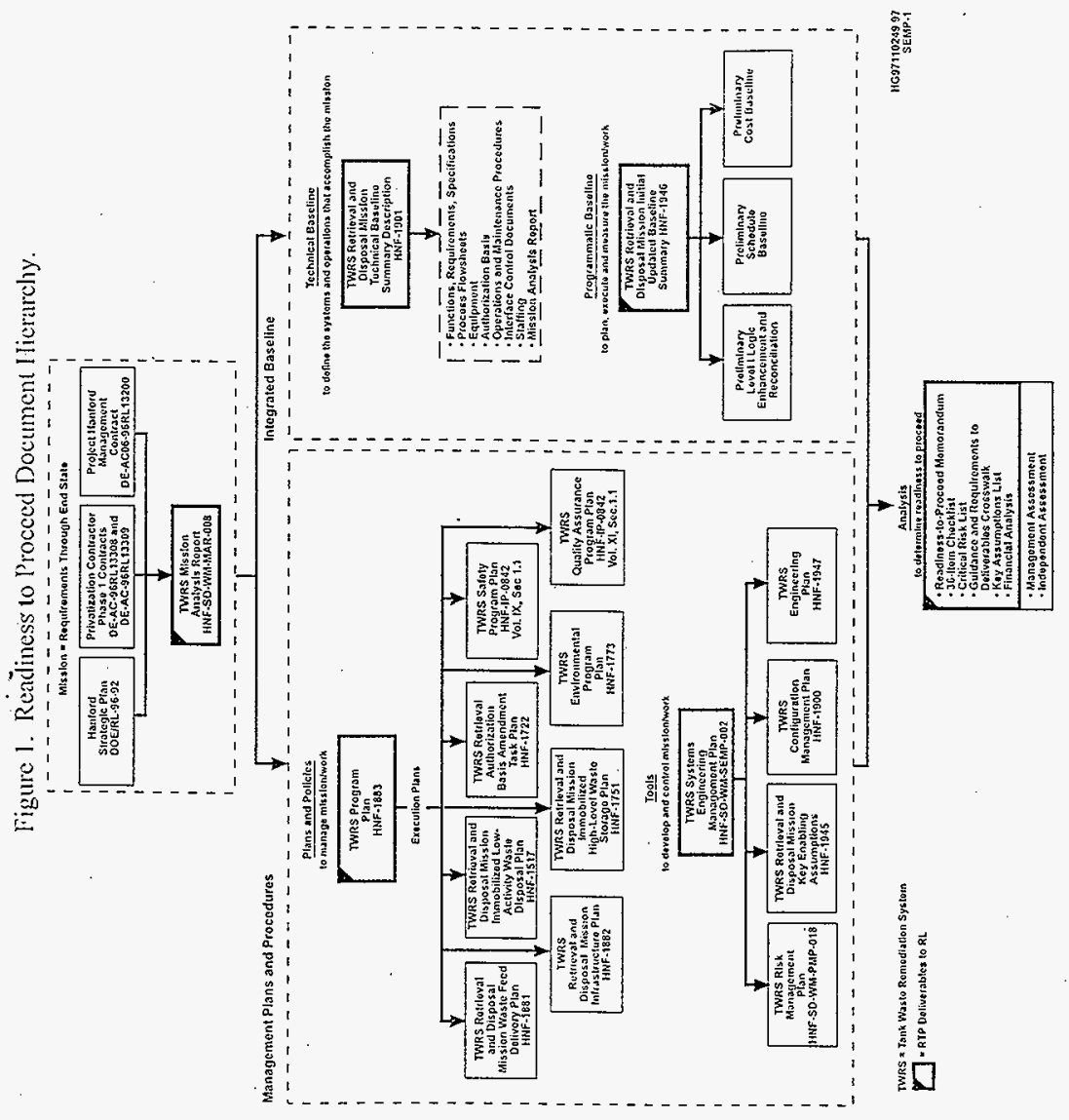


the Hanford Site Technical Database (HSTD). Specifically, results of changes in the following areas are included in this revision of the SEMP.

- Individual projects will use the Critical Decision (CD) milestones and life-cycle phases as described in DOE Order 430.1 GPG-FM-010, Project Execution and Engineering Management Planning; GPG-FM-015, Project Reviews; and GPG-FM-002, Critical Decision Criteria.

- The TWRS Project is now organized under the PHMC. This revision of the SEMP is focused on the systems engineering implementation for the Tank Waste Retrieval and Disposal Mission including the Phase 1 development of new and modified systems to deliver waste feed to the private contractors and to store and/or dispose of the immobilized waste products and process byproducts.

- Representation of the system architecture has been modified, resulting from a change in approach to the development of the HSTD for the Site. The HSTD identifies 'major facilities' as the top-level architecture for the Hanford Site. Lower-tier systems, structures, and components (SSCs) are derived beneath these major facilities. The HSTD assigns the following nine major facilities to TWRS: Single-Shell Tanks, Double-Shell Tanks, Immobilized Low-Activity Waste (LAW) Disposal Facility, the Immobilized High-Level Waste (HLW) Storage Modules, the Immobilized LAW Disposal Facility Addition, LAW Plant Phase 1, LAW/HLW Plant Phase 1, LAW Treatment Facility Phase 2, and HLW Treatment Facility Phase 2. The four treatment facilities are planned to be the responsibility of private contractors, with the exception of decommissioning and decontamination of the Phase 1 treatment facilities which is the responsibility of the TWRS Project. In addition, TWRS top-level architecture includes the Canister Storage Building modules and the portion of infrastructure development to support TWRS facilities. The TWRS Project staff has the responsibility to define the SSCs that must be developed (or modified) to meet the TWRS Project. The TWRS Project staff will verify that the existing SSCs meet the system requirements when they are used to perform mission functions.

- Technical requirements for TWRS SSCs will be captured in specifications following DOE Order 430.1 GPG-FM-010 guidelines, using the Level 1/Level 2 nomenclature consistent with the guide. The design-to technical requirements for a project will be contained in the specifications for the SSCs allocated to that project.

- The TWRS Project will use the requirements data contained in the HSTD to produce specifications and maintain the requirement traceability information for new systems development or modifications to existing systems. 
- A structured approach to interface control will be implemented. Interface Control Documents (ICDs) will be used to control physical interfaces.

- The TWRS Project will use interface data contained in the HSTD to produce the ICDs, ensuring consistency with the content of specifications.

\subsection{KEY PARTICIPANTS}

The TWRS contractor under the PHMC has primary responsibility for the implementation of this SEMP. For a more complete definition of roles and responsibilities, refer to the HNF-MP-001, Project Hanford Management Contract Management and Integration Plan (FDH 1997a), and HNF-1883, Tank Waste Remediation System Program Plan (Freeman 1998):

\subsection{DOCUMENT ORGANIZATION}

This document is organized in two major sections:

- Integrated Baseline Management (Section 2.0) - Defines the Integrated Baseline for TWRS and outlines the management controls that will be used to control and maintain the baseline

- Systems Engineering Process (Section 3.0) - Outlines the systems engineering process that will be used by TWRS throughout the life of the TWRS Project; primarily focusing on the continuing systematic development of a traceable, defensible Technical Baseline for new and modified systems developed for the Phase 1 system.

\subsection{INTEGRATED BASELINE MANAGEMENT}

This section provides an overview of the Integrated Baseline and the role of the Technical Baseline as its primary component. Also included are the control processes that will be used to manage the Technical Baseline.

\subsection{INTEGRATED BASELINE}

The TWRS Integrated Baseline is defined as the complete set of work scope, schedule, cost, and technical information used to define and manage the total program. Figure 2 shows the elements of the Integrated Baseline, their relationship to upper-level guidance documents, and 
HNF-SD-WM-SEMP-002 Rev 1

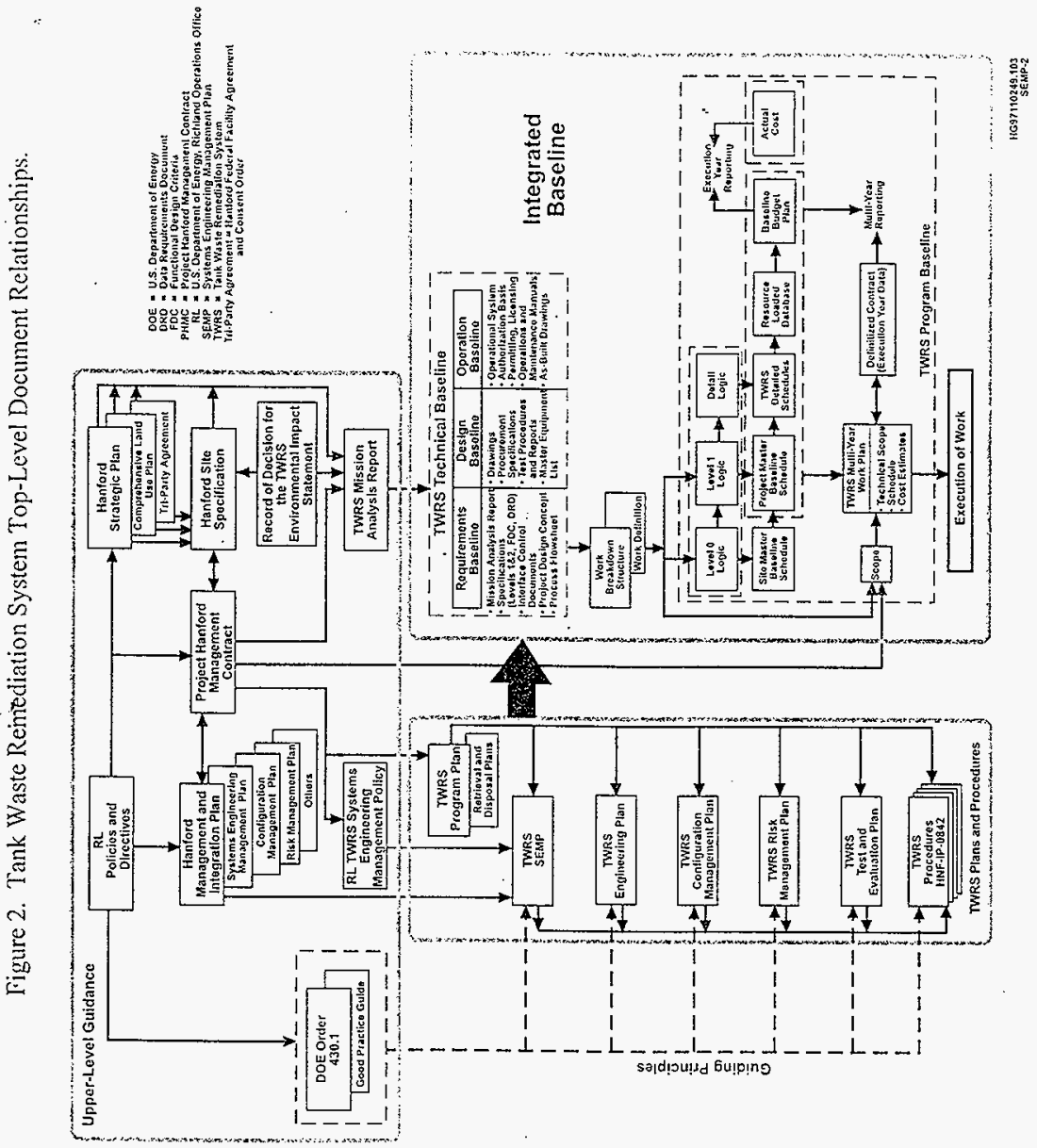


the TWRS plans and procedures that control the development of the Integrated Baseline. At present, the baseline definition for the near-term Phase 1 is at a much greater detail than the longer term Phase 2 and the future closure activities. The Integrated Baseline development is an ongoing activity and is subject to periodic system review.

The existing TWRS Integrated Baseline begins with HNF-SD-WM-MAR-008, Tank Waste Remediation System Mission Analysis Report (MAR) (Acree 1998), which captures the Hanford Site-level requirements assigned to TWRS, the definition of the initial and final end states of the TWRS Project, the major interfaces, and an initial assessment of the activities that TWRS must execute to be successful in achieving the defined mission. The top-level TWRS Technical Baseline has been derived from the MAR and used to develop and validate the TWRS Level 0 Logic (Figure 3). Lower-level decompositions of the Technical Baseline and resulting logic diagrams are developed as part of the engineering process to further define mission requirements. From these, the program develops work scope, cost, and schedule performance baselines which drive the annual multi-year work plan as described in Freeman (1998). The programmatic cost and schedule baselines mature along with the Technical Baseline. The management controls (e.g., configuration management, risk management, decision management) used to control the baseline are discussed further in this section.

This SEMP focuses on the systematic development of the Technical Baseline to ensure a complete and traceable engineering design solution to meet the mission needs and requirements. The Technical Baseline can be defined, in general, as the set of science/engineering equipment, facilities, materials, qualified staff, and enabling documentation needed to start up and complete mission objectives.

The Technical Baseline will be generated using the iterative systems engineering process defined in Section 3.0. The Technical Baseline starts with the TWRS MAR (Acree 1998). From this Level 1 specifications setting, the top-level requirements for each applicable system are prepared. Specific component requirements are captured in Level 2 specifications to which the component will be designed. As the Technical Baseline evolves over the life of TWRS and new systems are integrated into the existing operational system, the documents and systems that make up the Technical Baseline evolve from mission statements and requirements documents to design drawings and ICDs, then finally into the operational system. Figure 4 depicts the key elements of the Technical Baseline for both the TWRS Project level and for a given project within TWRS. In this SEMP, the Technical Baseline is divided into three categories that generally represent the evolving maturity of the Technical Baseline with time: (1) the Requirements Baseline, (2) the Design Baseline, and (3) the Operational Baseline. Further information on the present status of the TWRS Technical Baseline can be found in HNF-1901, Tank Waste Remediation System Retrieval and Disposal Mission Technical Baseline Summary Description (Treat et al. 1998). 


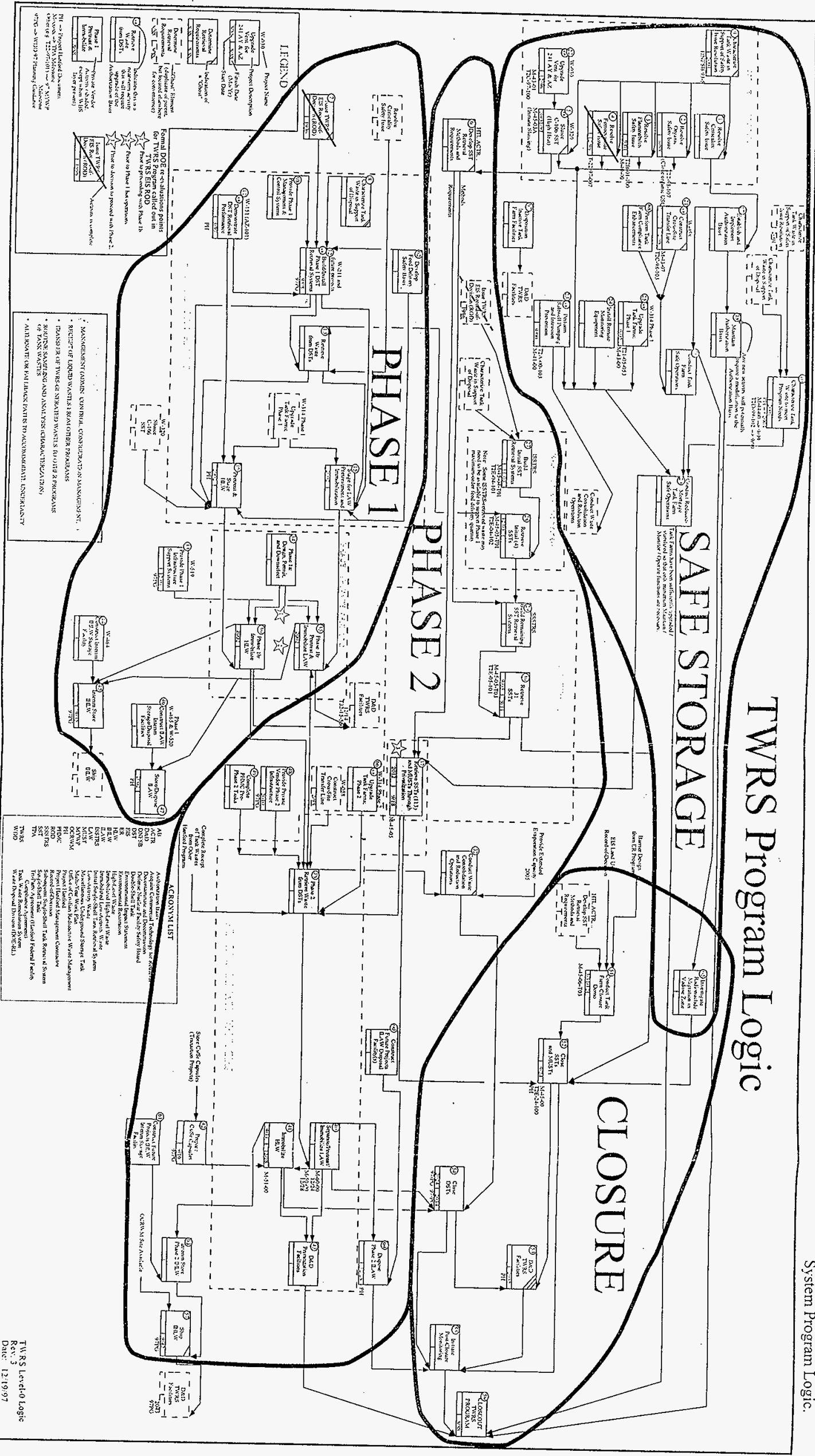

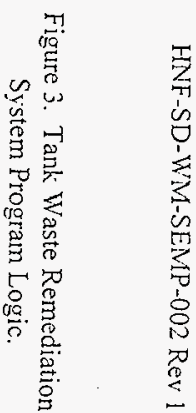


Figure 4. Tank Waste Remediation System Technical Baseline.

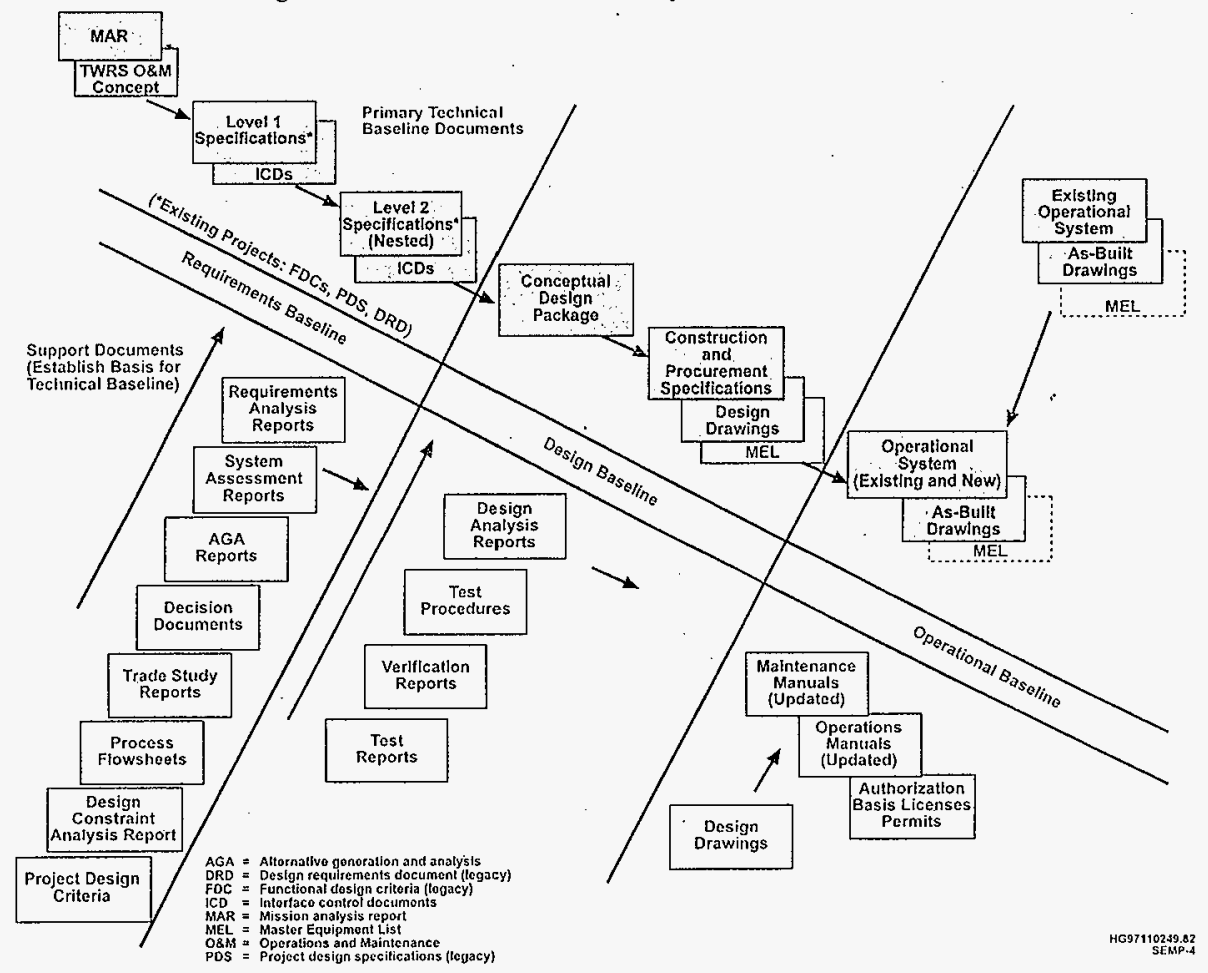




\subsection{SYSTEMS ENGINEERING MANAGEMENT PLAN IMPLEMENTATION}

The TWRS Project is made up of projects and existing operations in different stages of their life cycle. The tailored implementation of the systems engineering processes and requirements set forth in this document to a particular project will depend on (1) the complexity of the system under development and its need for systems engineering rigor and (2) the phase of development at the time the systems engineering process is introduced for ongoing projects.

A grading process will be used to establish an appropriate level of rigor for systems engineering implementation and associated documentation to be generated for a project. The grading criteria and process are defined in HNF-IP-0842, TWRS Administration, Volume IV, "Engineering," Section 1.2, "TWRS Systems Engineering Grading Guidelines" (LMHC 1997). Projects will evaluate the SSCs they are responsible for developing to determine the system engineering grading according to the complexity and risk associated with those SSCs. It is possible for a project to implement systems engineering differently for SSCs that it is responsible for developing.

Projects with a CD-1 date later than October 1,1997, will follow the processes defined in this SEMP. Ongoing projects (e.g., W-211, W-314, W-320, W-464, W-465, W-519, and W-520) will migrate their systems engineering practices to be consistent with this SEMP for Technical Baseline development as necessary based on risk associated with the maturity of their systems and budget constraints. The management disciplines of interface control, risk management, decision management, and configuration management will be required for all projects.

Planning for the implementation of this SEMP (application of the grading criteria and migration plans) for projects within the TWRS Project is the responsibility of the individual project manager. These plans will be documented and are subject to approval by management at an integration level above the project.

\subsubsection{Systems Engineering in Subcontracts}

Many TWRS activities will be performed by subcontractors. The scope and content of system engineering tasks allocated to the subcontractor depend on the type of task assigned and generally fall into three basic categories: (1) engineering services, (2) design development, and (3) procure-to-specification. System engineering tasking in the subcontract will be allocated based on the following general guidelines:

- $\quad$ Engineering Services-The standards and processes imposed by this SEMP will generally be allocated directly on the subcontractor.

- Design Development-For subcontractor activities that produce products that require integration with TWRS contractor system engineering processes, the 
subcontractor will be expected to use the standards and processes being followed by the TWRS contractor. For example, design efforts that affect interfaces with other projects will require interface design products consistent with HSTD implementation. If the products do not require direct interface with TWRS processes, subcontractor processes that are consistent with commercial practices will be acceptable.

- Procure-to-Specification-Subcontractors supplying off-the-shelf or build-tospecification equipment will generally not be required to perform system engineering tasks.

It is the responsibility of the TWRS organization preparing the subcontractor procurement package to determine the specific content and scope of the systems engineering tasks to be included in the subcontract.

\subsubsection{Systems Engineering Program Evaluation}

HNF-IP-0842, Volume IV, Section 2.12, "Systems Engineering Maturity Assessment" (LMHC 1997) will be used as a tool to provide periodic systems engineering process maturity self-assessment and improvement against industry and government standards. .

\subsection{MANAGEMENT OF THE INTEGRATED BASELINE}

This section describes the processes that are used to control the elements of the Integrated Baseline. Primary emphasis is on control processes for the Technical Baseline.

\subsubsection{Configuration Management}

Configuration management is an integrated approach to control the technical, cost, schedule, and administrative information necessary to manage the TWRS baseline.

Configuration management is used to establish and maintain consistency and traceability among source requirements, product information, and products. Configuration management focuses on application of five principal functions: Configuration management system management, configuration identification, configuration status accounting, change control, and configuration management assessments. The application of these configuration management functions is tailored to project requirements and life-cycle phases. Further details regarding implementation can be found in HNF-1900, Tank Waste Remediation System Configuration Management Plan (Vann et al. 1998) and subtier implementing plans and procedures. 


\subsubsection{Interface Management}

The TWRS Project will use ICDs as the vehicle to record agreements on technical requirements and design solutions across physical interface boundaries between two or more system elements. The ICDs record the definition of the physical boundary in the form of design information and drawings and document agreement between the owners of each side of the boundary. Interfaces exist at the Major Facility level as well as at architecture indentures below the Major Facility level. Interface data will be placed into the HSTD to provide configuration control, and the HSTD will be used to produce technical content of the ICD. The HSTD will also translate the ICD requirements into the appropriate sections of the Level 1 or Level 2 specifications.

Programmatic interfaces/agreements will be handled through contractual documents between contractors or in Memoranda of Agreement within TWRS, reserving the ICD for technical interface definition.

Refer to HNF-IP-0842, Volume IV, Section 2.8, "Interface Control"'(LMHC 1997), for further details regarding the implementation of interface control for TWRS.

\subsubsection{Risk Management}

The TWRS Risk Management Program will create a work environment where risks are identified, understood, and managed. The approach uses a bottom-up flow of risk data and information, based on risk and enabling assumption information generated from technical basis reviews. The technical basis reviews provide technical and cost information in support of the program logic decompositions. For those individual project baseline summary elements without technical basis reviews, the Risk Management Program will be based directly on the work breakdown structure (WBS) task structure.

The primary tool for communicating risks is the risk management list which identifies risks; describes their likelihood and consequences; and identifies residual risk, handling actions, and handling action status. Individual risk management implementation plans will be developed to meet specific HNF-SD-WM-PMP-018, Tank Waste Remediation System Risk Management Plan (Zimmerman 1998), requirements for each project baseline summary. Detailed guidance for performing risk management activities is provided in HNF-IP-0842, Volume IV, Section 2.6, "Risk Management" (LMHC 1997).

\subsubsection{Decision Management}

Decision management provides traceability for affected decisions through graded utilization of a robust and methodical decision-making process. A formal decision process will be employed by TWRS for decisions of major program importance. A simplified process will be 
employed for decisions of lesser magnitude. The decision maker or responsible manager will determine to what extent the full decision process is required for each particular decision. Decision management for TWRS will be accomplished according to HNF-IP-08+2, Volume IV, Section 2.7, "Decision Management" (LMHC 1997).

The TWRS will also maintain an overall compilation of major TWRS Project decisions, both required and completed, indexed for cross-reference with the Level 1 logic diagrams.

\subsubsection{Technical Requirements Traceability}

The TWRS Project will provide traceability of technical requirements defined for new system developments or modifications to existing systems. The systems engineering process (as defined in Section 3.2) describes a top-down approach for the definition of technical requirements and requires specified requirements to be traceable to sources documented in the TWRS MAR (Acree 1998), laws, regulations, codes, or documents generating this requirement (e.g., a demonstration test report or an analysis used to arrive at the requirement).

The TWRS Project is using the HSTD database to capture the requirements development for the new/modified system development and the production of specifications and ICDs. The HSTD also provides the capability to retain the traceability information for each requirement it contains. Traceability can be verified by using the HSTD to produce traceability reports. Refer to HNF-SD-TWR-CSUD-001, Tank Waste Remediation System Technical Baseline Database Manager Definition Document (Acree 1997), for further information on the usage of the HSTD for requirements traceability.

\subsubsection{Technical Reviews}

Reviews are conducted to assess the development of the Integrated Baseline and to verify conformance with requirements. The TWRS Project reviews as well as project-level (e.g., line items) reviews will be conducted.

2.3.6.1 TWRS Project Reviews. As required by the Record of Decision for the Tank Waste Remediation System, Hanford Site, Richland, WA (62 FR 8693), the following three reviews will be conducted to evaluate TWRS as a total system:

- Phase 1 Readiness to Proceed (before proceeding into Privatization Phase 1B)

- Phase 1 Operational Readiness Assessment (before the start of hot operations of Privatization Phase 1B)

- $\quad$ Phase 2 Readiness to Proceed (before proceeding into Privatization Phase 2) 
2.3.6.2 Project Reviews. Individual projects will conduct reviews to support the CD milestones as defined in DOE Order 430.1 GPG-FM-002, GPG-FM-010, and GPG-FM-015 for the SSCs that the projects are responsible to develop or modify. Other reviews may be added at the discretion of TWRS or project management.

Four reviews are required during a project's life cycle:

- Project Mission Review. A project mission review will be held before CD-1 to validate the project's need, scope, functions, requirements, and alternatives. The program managers are responsible to conduct the review and to present the information to the review authority. Participation from the Operations organization is expected. The review authority for the project mission review is the sponsoring TWRS manager or designee.

- System Functional Review. A system functional review will be held prior to CD-2. The objectives of a system functional review will be in accordance with DOE Order 430.1 GPG-FM-015 (including verification of conformance with requirements), as tailored for the specific project. The program manager is responsible to conduct the review and to present the information to the review authority. The review authority for the system functional review is the sponsoring TWRS manager or designee.

- Detailed Design Review. A detailed design review will be held prior to CD-3. The objectives of the detailed design review will be in accordance with DOE Order 430.1 GPG-FM-015 (including verification of conformance with requirements), as tailored for the specific project. Detailed design review success criteria will reflect the Good Practice Guide objectives as tailored. The project manager is responsible to organize the review and to present the information to the review authority. The review authority for the detailed design review is the sponsoring TWRS manager or designee.

- Operational Startup Review. An operational startup review will be held before turning over new SSCs to tank farm operations for use. This review will verify (1) the SSC functionality, (2) that the physical configuration matches the drawings, and (3) the suitability of the operations and maintenance (O\&M) technical data. This review will comply with the requirements of HNF-IP-0842, Volume IV, Section 3.12, "Acceptance for Beneficial Use" (LMHC 1997). At the successful completion of this review, the SSCs will be turned over to Operations for use. The project manager review authority is the sponsoring TWRS manager or designee. 


\subsubsection{Technical Performance Measurement}

The TWRS Project will develop and track key Technical Performance Measures. Technical Performance Measures are significant technical parameters that provide insight and trends into the progress of the program toward achieving mission technical goals. The TWRS Project will use Technical Performance Measures to:

- Gain insight into the maturity of the engineering design

- Identify key parameters for the Test and Evaluation Program

- Provide management insight into overall program, decision, and risk management.

The HNF-IP-0842, Volume IV, Section 2.4 "Technical Performance Measurement" (LMHC 1997), contains additional information on the implementation of Technical Performance Measurements for the TWRS Project.

\subsubsection{Systems Engineering Culture}

Systems engineering will be practiced by managers and engineers. The systems approach will be institutionalized by the TWRS contractor.

\subsection{SYSTEMS ENGINEERING PROCESS}

This section provides (1) the details of how systems engineering will be applied to the development of the TWRS Technical Baseline, (2) the required systems engineering analyses, and (3) an outline of how the requirements baseline will be used to define projects. This section also describes how test and evaluation will be performed on the TWRS Project and provides a matrix that defines major products of the requirements baseline. Organizational roles and responsibilities for performing the activities described in this section are identified in HNF-IP-0842, Volume IV, Section 1.3, "TWRS Systems Engineering Roles and Responsibilities" (LMHC 1997).

The TWRS Project will employ the systems engineering process progressively throughout the effort to define requirements, designs, and solutions that achieve program objectives. The systems engineering process is applied iteratively as many times as needed to develop the physical solutions to the level of detail appropriate to the specific life-cycle phase. 


\subsection{SYSTEMS ENGINEERING PROCESS OVERVIEW}

Figure 5 is a graphical overview of the process the TWRS Project will use to establish system requirements and architecture. This process is consistent with the guidance in DOE Order 430.1, Good Practice Guides, and with commercial practices (e.g.. IS-632 [EIA 1994]).

The steps of the systems engineering process will be performed sequentially to define the SSCs. The process will be applied iteratively until the SSCs are defined to a level of detail at which the requirements for elements of the system can be clearly specified for construction or procurement. While Figure 5 illustrates a sequential process, the steps of the process will be going on simultaneously for different elements of the system and at different levels of detail depending on the priorities of the program, the level of complexity and risk associated with the SSC being developed, and the life-cycle phase of development for the SSC.

While there are several different conventions that can be used to illustrate the systems engineering process, the basic process is generally: (1) define what must be done (i.e., establish functions); (2) develop how well it must be done (i.e., establish requirements); (3) assess alternatives and select the best approach (i.e., develop physical architecture); and (4) verify that results will meet mission requirements (i.e., test). The systems engineering process (Figure 5) to be used in the TWRS Project is based on and consistent with the process outlined in DOE Order 430.1, GPG-FM-10. The process has been tailored to meet TWRS-specific needs.

\subsection{SYSTEMS ENGINEERING PROCESS APPLICATION TO TANK WASTE REMEDIATION SYSTEM}

'This section defines the systems engineering process that is being applied within the TWRS Project. The Technical Baseline evolves through three phases: requirements baseline, design baseline, and operational baseline. Ongoing operations and projects will be reviewed and updated based on the evolving technical baseline. Expanded activities (e.g., new projects) to address the retrieval and disposal mission will be developed considering the existing operational baseline. The composition of these baselines is identified in Section 3.6. The technical data (e.g., drawings and operations manuals) that define the tank farms and related infrastructure form the operational baseline. The existing operational baseline will be modified as necessary to establish the TWRS Phase 1, Phase 2, and Closure systems.

The systems engineering process will establish the requirements baseline for major facilities allocated by Hanford Site Systems Engineering to the TWRS Project for development. These facilities are identified in the HSTD and TWRS MAR (Acree 1998) and are listed in Table 1. These major facilities interface with the privatized TWRS facilities (i.e., LAW Plant Phase 1, LAW/HLW Plant Phase 1, LAW Treatment Facility Phase 2, and HLW Treatment Facility Phase 2). Similarly, TWRS major facilities must interface with other Hanford Project 
HNF-SD-WM-SEMP-002 Rev 1

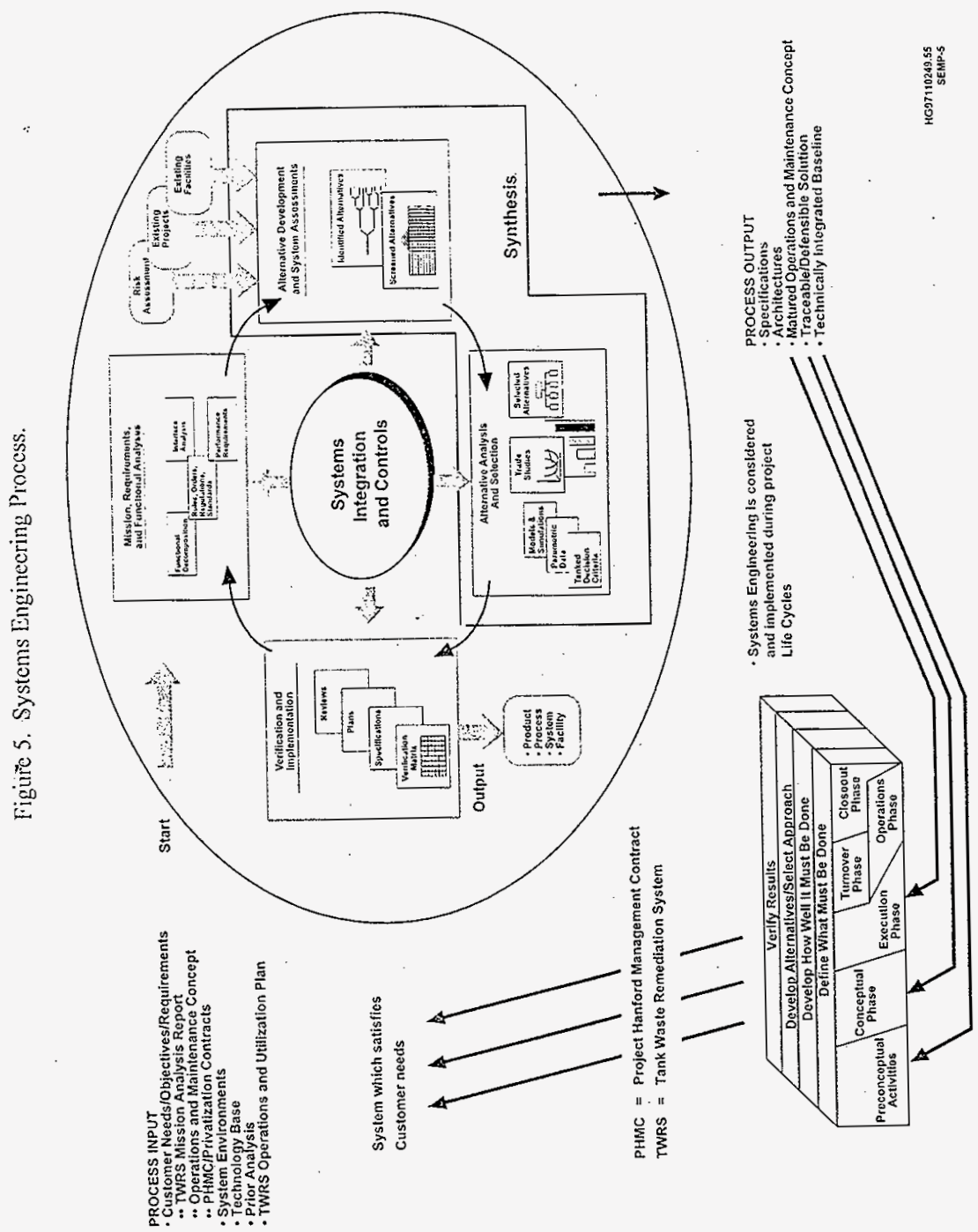


facilities. Major facility requirements will be the basis for developing a requirements baseline for the subsystems and components. The requirements baseline documents will be used by projects to establish a design baseline. The design baseline will be updated after construction and integrated into the existing operational baseline at completion of turnover. The processes outlined in this section detail the requirements baseline and design baseline development.

Table 1. Tank Waste Remediation System Major Facilities by Phase Allocated to the Tank Waste Remediation System Contractor.

\begin{tabular}{|c|c|c|}
\hline Phase 1 & Phase 2 & Closure \\
\hline $\begin{array}{l}\text { - SST System } \\
\text { - DST System } \\
\text { - CSB } \\
\text { - ILAW Disposal System } \\
\text { - ILAW Disposal System Addition } \\
\text { - Central Plateau Infrastructure }\end{array}$ & $\begin{array}{l}\text { - SST System } \\
\text { - DST System } \\
\text { - IHLW Storage System } \\
\text { - ILAW Disposal System } \\
\text { - ILAW Disposal System Addition } \\
\text { - CSB } \\
\text { - Central Plateau Infrastructure }\end{array}$ & $\begin{array}{l}\text { - SST System } \\
\text { - DST System } \\
\text { - Phase I LAW Plant } \\
\text { - Phase } 1 \text { HLW/LAW Plant } \\
\text { - IHLW Storage System } \\
\text { - ILAW Disposal System } \\
\text { - ILAW Disposal System } \\
\text { Addition } \\
\text { - CSB } \\
\text { - Central Plateau Infrastructure }\end{array}$ \\
\hline
\end{tabular}

These systems are evolutions of the current system.

'The TWRS contractor is only responsible for the TWRS portions of these major facilities.

These systems are evolutions of the Phase 1 systems bearing the same name.

These systems represent an evolution to a closed, monitored state.

These facilities will be decontaminated and decommissioned at the end of their bencficial lite. $\mathrm{CSB}=$ Canister Storage Building.

DST $=$ couble-shell tank.

$H L W=$ high-level waste.

IHLW $=$ immobilized high-level waste

ILAW = immobilized low-activily waste.

L.AW $=$ low-activity waste. SST = single-shell tank.

-TWRS = Tank Waste Remediation System.

The following constraints influence systems engineering definition:

1. Hanford Strategic Plan (RL 1996a) outlines the goals for Hanford Site cleanup

2. The Record of Decision for the Tank Waste Remediation System, Hanford Site, Richland, Washington (62 FR 8693) and associated DOE/EIS-0222D, Draft Hanford Remedial Action Environmental Impact Statement and Comprehensive Land Use Plan (DOE 1996) outline an approved strategy for retrieval, treatment, and disposal of tank waste in phases

3. The DOE acquisition strategy for TWRS which includes privatization of the immobilization facilities 
4. The timelines imposed on the TWRS Project by the Hanford Federal Facility Agreement and Consent Order (Tri-Party Agreement) (Ecology et al. 1996) and the DOE

- 5. The constraints imposed on the Hanford Site by regulations contained in Code of Federal Regulations, Washington Administrative Codes, and DOE Orders

6. Subcontract between Fluor Daniel Hainford Company, Inc., and Lockheed Martin Hanford Corporation, Contract 80232764-9-K1001 (FDH 1996)

7. The legacy TWRS operational baseline

8. Projects in design and construction phases modifying the existing system.

Specific requirements with respect to the first five constraints were imposed by contract (Item 6) and used to generate the TWRS MAR (Acree 1998). The last two constraints influence how systems engineering principles will be applied to generate requirements. Given these eight constraints, a TWRS Project Technical Baseline development strategy was developed with the following tenets.

- Focus Technical Baseline development on the TWRS Phase 1 operations. Technical Baseline development to support the balance of mission systems (Phase 2 and Closure) will be conducted in parallel as needed.

- The Technical Baseline will be developed using a top-down systems engineering process which takes into account the existing TWRS systems and ongoing upgrade projects. This will be integrated with bottoms-up planning. Existing systems will be modified or supplemented with new systems to fulfill defined functions and requirements.

- The existing projects will continue while the top-down process is developed. It is a priority to keep these projects progressing to ensure Phase 1 waste feed delivery on schedule. Reviews, baseline comparisons, and analyses will be conducted in the interim to manage risks. Initial comparisons have indicated it is prudent and reasonable to continue work on current construction projects. Reviews and baseline comparisons will be conducted as additional information becomes available and as projects progress through their life-cycle phases.

In addition, development of the Technical Baseline will emphasize cost effectiveness while balancing performance requirements and schedule constraints. Considerations will include the following:

- Benefits of flexibility and expansion as applicable to other mission areas and phases 
- Benefits of standardizing components

- Validation and verification methods that ensure the system satisfies the mission need based on requirements and cost effectiveness.

This strategy is implemented as illustrated in Figure 6. This figure illustrates how upper-tier requirements and the mission need feed through the PHMC to the TWRS MAR (Acree 1998). The MAR, the existing system capability and conditions, and the existing project design requirements then feed systems engineering analysis to establish a requirements baseline. The systems engineering analysis applies the process described in Section 3.1 to define TWRS configuration for each phase.

Figure 7 provides an overview of how this systems engineering analysis will proceed for the TWRS. Decisions are made during the systems engineering analysis about which portions of the existing system will be used as is, which will be modified, and what new SSCs are needed. These decisions, together with the requirements baseline, will be used to define projects (project definition details are provided in Section 3.3). The project definition activity will lead to validation and/or modification of existing project scope and requirements and to launching new projects. This model will be applied to achieve phased completion of TWRS for Phase 1, Phase 2, and Closure.

\subsubsection{Mission Analysis}

The TWRS MAR (Acree 1998) documents the mission on which to build the TWRS Technical Baseline. Top-down Technical Baseline development will be traceable to the MAR. The MAR indicates how the HSTD functions are allocated to TWRS major facilities and defines top-level interfaces to the TWRS. This provides the starting point for TWRS functions and requirements development. In addition, the MAR provides the externally imposed system-level constraints to be applied to TWRS. A project defined by the top-down process will not require its own mission analysis, with the exception of demonstration projects. Demonstration projects will develop a mission analysis that will specify the need for the project and the specific questions and/or HSTD critical issue it will answer. Demonstration project mission analyses will be developed in accordance with HNF-IP-0842, Volume IV, Section 3.1, "Mission Analysis" (LMHC 1997). 
Figure 6. Tank Waste Remediation System Technical Baseline Development Strategy.

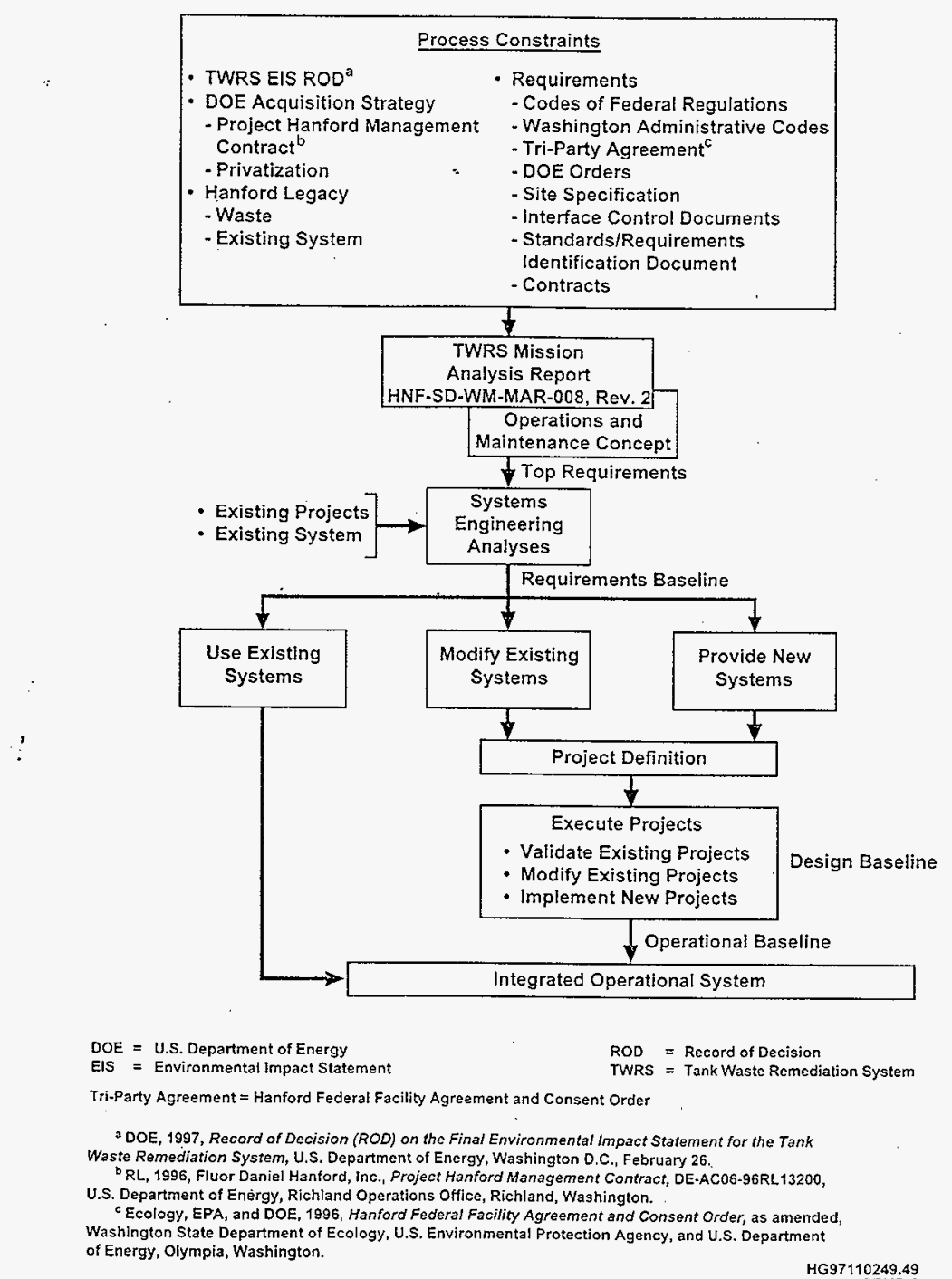

\footnotetext{
EIS = Environmental Impact Statement

TWRS = Tank Waste Remediation System

Tri-Party Agreement = Hanford Federal Facility Agreement and Consent Order

'DOE, 1997, Record of Decision (ROD) on the Final Environmental Impact Statement for the Tank aste Remediation System, U.S. Department of Energy, Washington D.C., February 26.

1996, Fluor Daniel Hantord, inc., Project Hanford Management Contract, DE-AC06-96RL13200,

Washington State Department of Ecology, U.S. Environmental Protection Agency, and U.S. Department

of Energy, Olympia, Washington.

ROD = Record of Decision 
Figure 7. Tank Waste Remediation System Systems Engineering Analysis Overview.

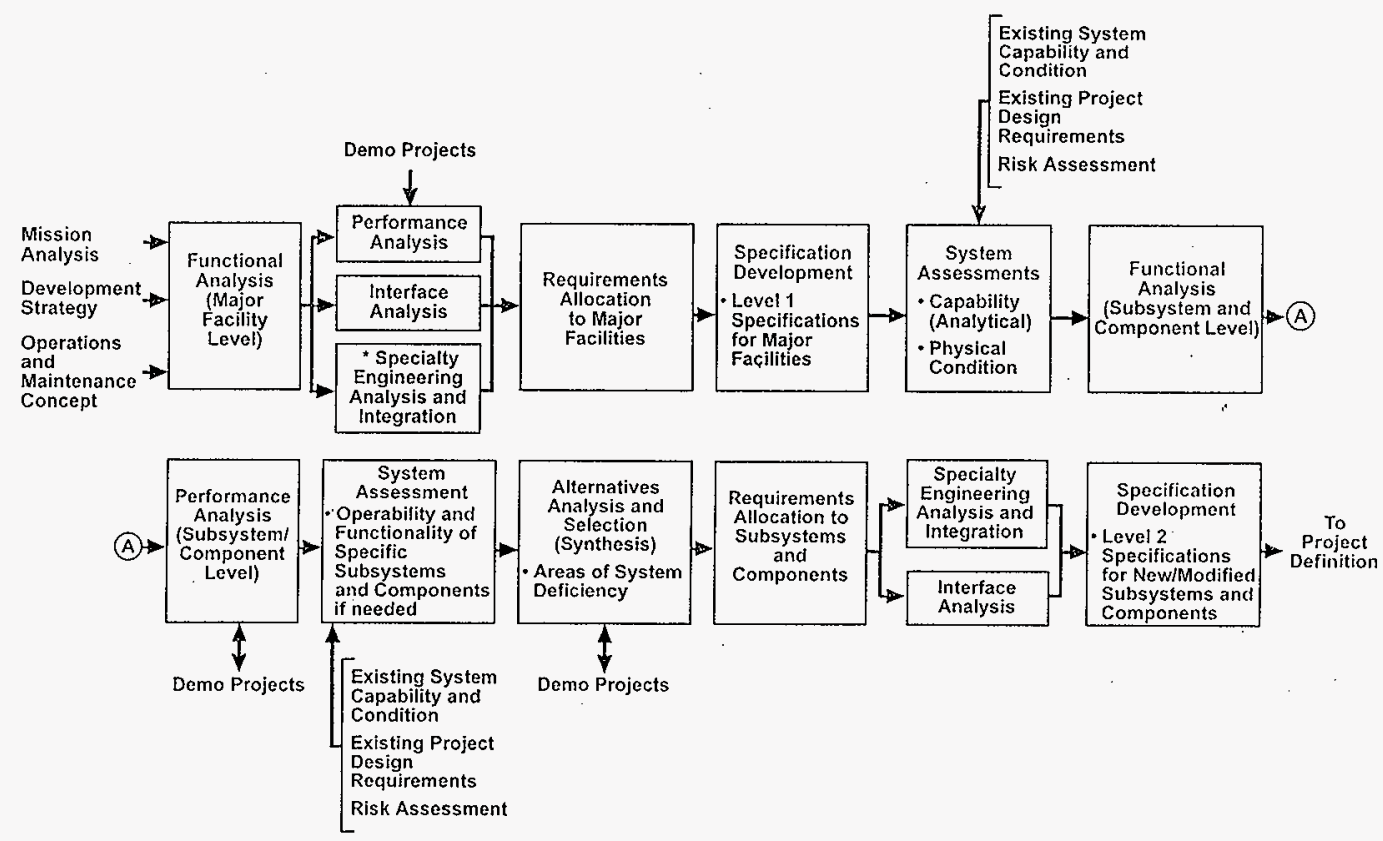




\subsubsection{Operations and Maintenance Concept}

An (O\&M) concept will be documented to summarize how the TWRS Project is operated and maintained. This concept will communicate O\&M decisions to guide requirements and design development activities. This concept will help organizations keep a common vision for system O\&M. The TWRS Project O\&M concept will evolve in detail, starting as a strategy and top-level concepts. The initial version of this concept will describe specific constraints on system operation. Some existing constraints include the HNF-SD-WM-BIO-001, Tank Jiaste Remediation System Basis for Interim Operation (BIO) (FDH 1997b) and existing conduct-ofoperations limits on the number of personnel required to operate the system, the number of shifts per day the system will operate under normal conditions, and required responses to abnormal conditions. This information will provide a point of departure for reviewing expanded activity $O \& M$ concepts against existing O\&M concepts. The O\&M concept will be updated as necessary to incorporate expanded activities.

\subsubsection{Functional Analysis}

Functional analysis determines which activities an SSC must perform and the sequence of those activities to achieve the mission. This analysis will be performed in accordance with HNF-IP-0842, Volume IV, Section 3.2, "Functions and Requirements Analysis and Allocation" (LMHC 1997). The starting points for major facility functional analyses are documented by the TWRS MAR (Acree 1998). These functions will be decomposed into lower-level functions that more clearly and completely define major facility functional behavior. The results will be translated into system requirements and recorded in Level 1 specifications (refer to Section 3.2.10 for specification definitions).

Functional analyses below the major facility level will follow development of the relevant Level 1 specification(s) and the subsequent system assessment. These analyses will decompose functions allocated to major facilities to arrive at subsystem and component functions. This next level of decomposition will be used to generate Level 2 specifications. Results of functional analyses will be translated into the HSTD. Functional analysis will continue until required specifications are developed.

\subsubsection{Performance Requirements Analysis}

Performance analyses determine how well the SSCs must perform to achieve the mission. Analyses will be performed based on each level of functional analysis and accomplished in accordance with HNF-IP-0842. Volume IV, Section 3.2, "Functions and Requirement Analysis and Allocation" (LMHC 1997). The requirements derived will be allocated to functions defined during functional analysis. Performance analysis can be achieved using a combination of analytical techniques such as time-line analysis, queuing models, chemistry models, mass/energy balance, and several other means of applying scientific and engineering principles. The Hanford 
HNF-SD-WM-SEMP-002 Rer 1

Tank Waste Operation Simulator model is available as a tool for resolving waste stream volume and composition issues.

In some cases, determination of performance requirements will require testing. When such cases are identified, a demonstration project will be defined and proposed. Definition of a demonstration project includes generation of a MAR (refer to Section 3.2.1), identification of the requirements being derived, and a schedule and cost estimate.

Requirements analyses will be documented in referenceable reports that provide requirements traceability. Analytical details, including equations, graphs, and flowsheets, will be included in these reports as appropriate. The results will be allocated to appropriate functions and recorded in the HSTD. Performance analysis, together with the functional analysis, will be used to drive interface analyses, system analytical assessments, alternative analyses, and selection.

\subsubsection{System Assessments/Evaluations}

There is a need to determine the extent to which the existing system is able to perform the mission. These decisions will be based on analytical and/or physical assessments of the system. An analytical assessment will evaluate the current system waste feed capability (as recorded in its operational baseline data) and modifications planned by specified existing projects against the requirements of Level 1 specifications. Follow-on assessments of a specific SSC may be performed later, as indicated in Figure 7.

Physical assessment adds information of actual system operability and physical conditions to identify degraded or unsafe SSCs. This analysis will be accomplished through a combination of maintenance records evaluation, physical inspections, operability tests, and cognizant engineer interviews. These data will be combined with analytical results to reveal areas of system inadequacy. The magnitude of the inadequacies will be balanced against the factors indicated in Section 3.2.11 to determine whether SSC modification and/or replacement is justified. These analyses and results will be documented in systems assessment/evaluation reports. Decisions made from this activity will focus alternatives analysis and specification development on the areas where new and modified SSCs are needed.

\subsubsection{Alternative Analysis and Selection (Synthesis)}

Where new equipment is needed to perform system functions (e.g., waste retrieval), an evaluation of alternative system technologies and configurations (i.e., architectures) is needed. Potential solutions will be evaluated using HNF-IP-0842, Volume IV, Section 3.3, "Alternative Generation and Analysis" (AGA) (LMHC 1997). The AGAs will compare competing system architectures against the factors listed in Section 3.2.11. The complexity of AGAs will vary with the complexity of the decision being made. Some AGAs are expected to be very simple 
(completed within hours), while others may be extensive. The AGAs will also consider constraints levied by the Code of Federal Regulations, Washington Administrative Code, DOE Orders, and Standards/Requirements Identification Documents specific to the technologies being evaluated. The AGAs will be documented in a formal report. The HNF-IP-0842, Volume IV, Section 2.7, "Decision Management" (LMHC 1997), will be used to select and document one of the alternatives analyzed in the associated AGA.

To select appropriate technologies, testing may be required. In cases where risk warrants, a demonstration program may be required to prove capability. When such cases are identified, a demonstration project will be defined and proposed. Definition of a demonstration project includes generation of a project mission analysis (refer to Section 3.2.1), an evaluation of the risks being addressed, and a schedule and cost estimate. Approval of such a project rests with the TWRS Project manager and the DOE, Richland Operations Office.

\subsubsection{Requirements Allocation}

The functions and requirements developed during the analyses previously described will be allocated to major facilities based on the facility descriptions provided in the HSTD. The results of this allocation will be input into the HSTD to enable generation of Level 1 specifications. The HSTD already contains some functions allocated to the major facilities that need to be considered when performing this activity. Functions and requirements developed during lower-level analyses will be allocated to specific subsystems and components, as dictated by an AGA. The results of these allocations will be used to generate Level 2 specifications.

\subsubsection{Interface Analysis}

For major facilities, interface analysis coincides with performance analysis. This can take place at the same time because major facilities have already been defined. Specific major facility interfaces are identified in the HSTD and in HNF-SD-WM-SDS-007, Hanford Site Cleanup Interface Control Document Matrix (Lee 1997). Interface analysis establishes requirements for the interfaces between physical SSCs (not organizations). This activity is normally based on the performance analysis work previously discussed. Results will be input into the HSTD. The ICDs will be generated to document and control these requirements. The ICDs will comply with the TWRS ICD Definition Document (Acree 1997). This information will also be translated into the appropriate specification sections. The ICDs will be controlled as prescribed in Section 2.3.2. For subsystems and components, interface analyses will commence following requirements allocation. It is important that early recognition of required interfaces is established and initial agreements are reached and documented between the owners of each side of the boundary addressed in the interface. 


\subsubsection{Specialty Engineering Analysis and Integration}

Specialty engineering participation on program/project planning, requirements development. design development, testing, and turnover provides the continuity between lifecycle phases. Input from specialty engineering disciplines early in the prograni/project development ensures necessary and sufficient requirements are considered and integrated in time to result in a system that meets mission requirements with minimum redesign and rework. Program and project managers will plan for, and obtain, the appropriate engineering support required for their work. In addition to project and process engineering, the following disciplines will be used in baseline development as specified in HNF-1947, Tank Wraste Remediation System Engineering Plan (Rifaey 199.8). Specialty engineering analysis results will be documented and traceable. Results will be used during functional and performance analyses and/or input into the appropriate SSC specifications.

Specialty Engineering disciplines to be integrated include:

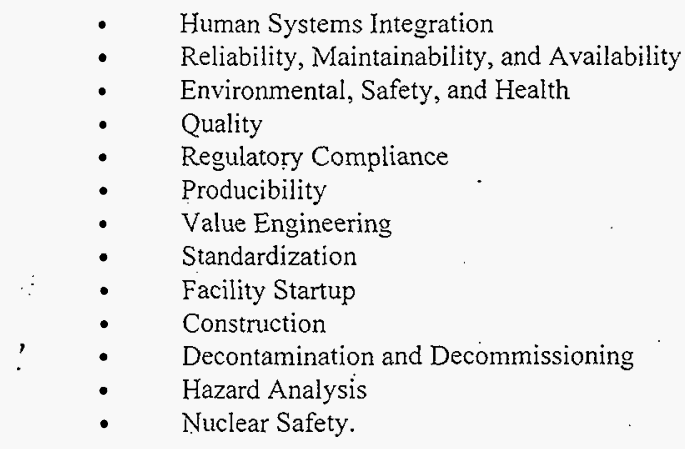

\subsubsection{Specification Development}

Level 1 (i.e., system) specifications will be generated in a prioritized manner for the major facilities identified in Table 1 and will be generated in accordance with HNF-IP-0842, Volume IV, Section 3.2, "Functions and Requirements Analysis and Allocation" (LMHC 1997). Level 2 (i.e., subsystem, component) specifications will be generated for applicable SSCs in accordance with HNF-IP-0842, Volume IV, Section 3.14, "TWRS Level 2 Specification Development Guide" (LMHC 1997). The specific Level 2 specification that will be generated will be determined as a result of decisions made stemming from the system assessment and alternatives analysis. Specifications will be generated from data contained within the HSTD. A specification can be printed directly from this database. 


\subsubsection{Design Optimization}

The purpose of design optimization activities is to determine the most cost-effective solution for a given system need and to balance requirements across multiple activities. The TWRS Project will integrate the results of its activities and perform design optimization studies as required to ensure a balanced system. When a needed trade study is identified, the study will be managed using the decision management process specified in Section 2.3.4. Studies will consider the following factors when making their trades:

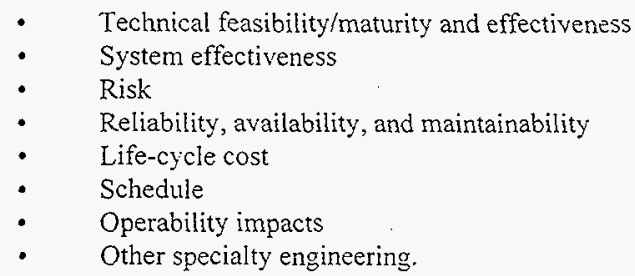

These factors will be tailored to support the specific area of evaluation or optimization.

\subsection{PROJECT DEFINITION}

An activity is required to package the acquisition of new and modified SSCs into discrete projects. This activity will evaluate technical, work scope/synergy, cost, schedule, and business factors to define projects. The result of this activity will be the validation of existing projects, modification of existing projects to better serve TWRS needs, and definition of new projects.

A project will receive its Technical Baseline by a process of allocating SSCs from the TWRS architecture tree, as illustrated in Figure 8. Each project will be given the following items to establish its baselines:

- Specifications for the required SSCs. A Level 1 specification may provide the scope for a project if the SSCs can be managed, designed, and deployed as a discrete unit. Level 2 specifications will be required for SSCs that need further decomposition.

- The associated ICDs

- A project design criteria documenting the quantities and locations of the SSCs to be provided

- A Statement of Work stating project work requirements. 
HNF-SD-WM-SEMP-002 Rev 1

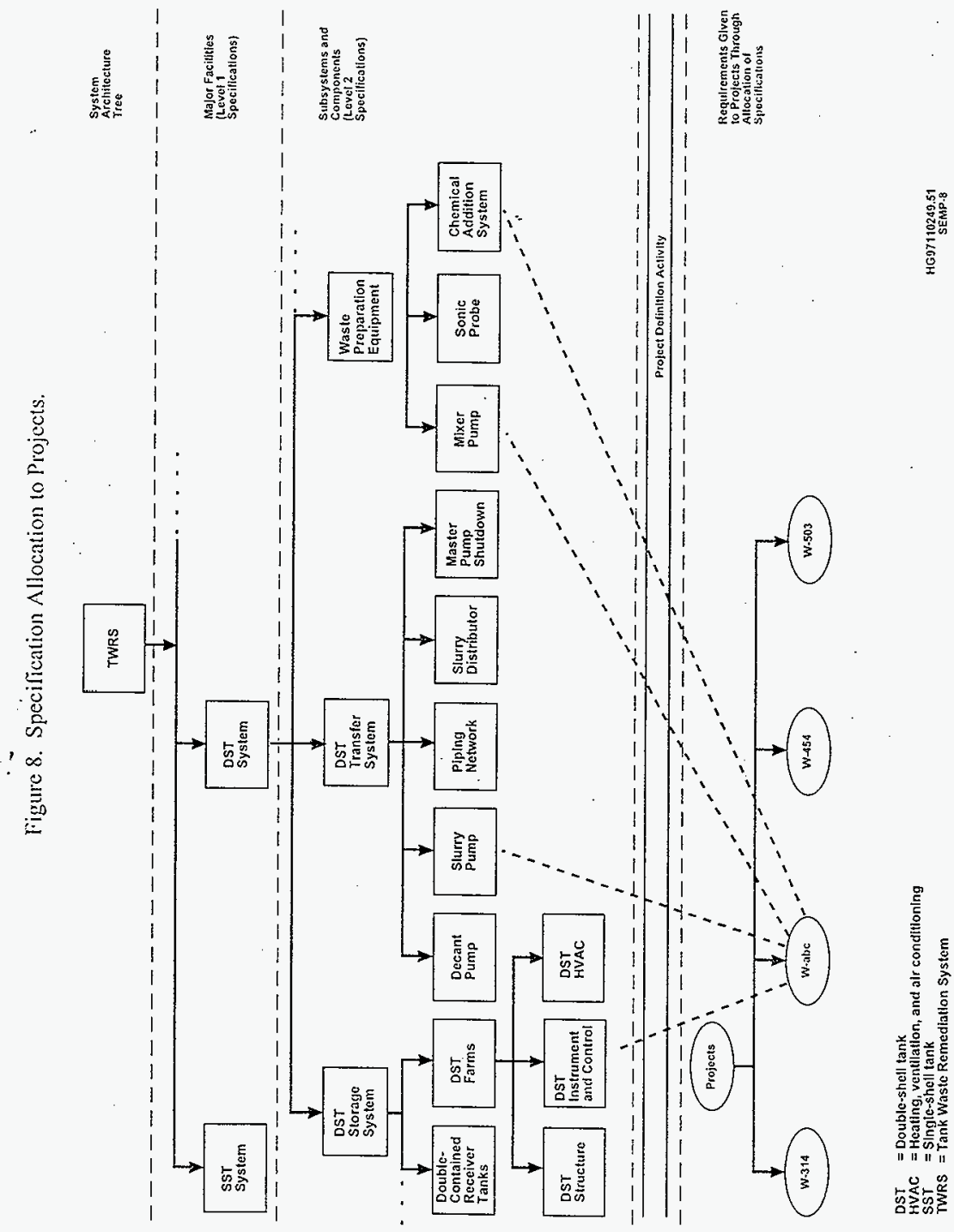


Projects initiated in this manner do not need a separate project mission analysis or SEMP. New projects will be formed and a team assigned when the above package has been assembled. The project team will work with the program to obtain CD-1 and CD-2. After CD-2, projects will be responsible for (i.e., lead) completion of the remaining project phases and critical decisions. If specifications or other technical data subordinate to those provided by the TWRS Project are needed, the project is responsible to develop them.

\subsection{DESIGN BASELINE DEVELOPMENT}

Projects will develop design baselines for the SSCs within their scope in accordance with Rifaey (1998). The process for baseline development and the required documents which form the design baselines will be in accordance with this plan. Existing projects will base their designs on the combination of their existing requirements documents and/or on those additional requirements baseline documents required in their project-specific systems engineering planning. Newly formed projects will base their design baselines on the project definition data provided by the TWRS Project, as outlined in Section 3.3.

\subsection{PHYSICAL SYSTEM TEST AND EVALUATION}

The TWRS Project will conduct the Test and Evaluation activities necessary to ensure (1) design solutions comply with specified requirements, (2) delivered or constructed systems comply with approved design drawings and construction/procurement specifications, (3) systems are properly installed and integrated into existing systems, (4) procedures are consistent and compatible with equipment/systems as constructed, (5) systems operate safely upon turnover, and (6) the TWRS Project operational system continues to operate as designed throughout its intended life. The Test and Evaluation Program for the TWRS Project is defined in HNF-2029, Tank Waste Remediation System Test and Evaluation Plan (Peck 1998).

\subsection{MAJOR PRODUCTS}

Table 2 identifies major products that comprise the Technical Baseline. The table points to the SEMP section that describes the product development, identifies the appropriate baseline, provides a description of each product's purpose and use, identifies format and content requirements, and identifies the principal activity responsible for its development. The last column states the extent to which the product's data are contained in the HSTD. Roles and responsibilities for generating this information are identified in HNVF-IP-0842. Volume IV, Section 1.3 "TWRS Systems Engineering Roles and Responsibilities" (LMHC 1997). 
Table 2.- Bascline Documents. (7 Shects)

\begin{tabular}{|c|c|c|c|c|c|c|}
\hline Product & $\begin{array}{l}\text { SEMP process } \\
\text { reference } \\
\text { section }\end{array}$ & $\begin{array}{l}\text { Baseline } \\
\text { Category }\end{array}$ & Purpose/use & $\begin{array}{l}\text { Format/ } \\
\text { content/ } \\
\text { procedure }\end{array}$ & Responsibility & Relationship to I-ISTD \\
\hline $\begin{array}{l}\text { MAL } \\
\text { (Acre 1998) }\end{array}$ & 3.2 .1 & $\begin{array}{l}\text { Requirements } \\
\text { Baseline }\end{array}$ & $\begin{array}{l}\text { listablishes the purnose and top-level requirements for a } \\
\text { system. It is used as the starting point for systems analysis } \\
\text { and other work. The MAR contains TWRS data assigned by } \\
\text { the site analyses, including major facilities definitions, } \\
\text { requirements, functions, and interfaces. There will be one } \\
\text { MAR for the TWRS. }\end{array}$ & $\begin{array}{l}\text { IINF-IP-0842, } \\
\text { Volume IV, } \\
\text { Section } 3.1 \\
\text { (1,MIIC 1997) }\end{array}$ & $\begin{array}{l}\text { TWRS General } \\
\text { Manager }\end{array}$ & $\begin{array}{l}\text { MAR requirements are } \\
\left.\text { residem in } 1 \mathrm{~S} S^{\prime}\right) \text {. The } \\
\text { doctument cannot be } \\
\text { printed fom there. }\end{array}$ \\
\hline $\begin{array}{l}\text { O\&M Concept } \\
\text { Doctmment }\end{array}$ & 3.2 .2 & $\begin{array}{l}\text { Requirements } \\
\text { Baseline }\end{array}$ & $\begin{array}{l}\text { Summarizes how the TWRS will be operated and maintained } \\
\text { during each operational phase. It will communicate O\&M } \\
\text { decisions to the various groups developing the TWRS so } \\
\text { groups will have a consistent concept from which to work. } \\
\text { This document will.guide requirements development, design, } \\
\text { and specialty analyses. }\end{array}$ & None specilied & $\begin{array}{l}\text { lank Waste } \\
\text { Operations }\end{array}$ & $\begin{array}{l}\text { Reguirements will be } \\
\text { resident in ISS"ID. The } \\
\text { doctument will not be } \\
\text { printed lion there. }\end{array}$ \\
\hline $\begin{array}{l}\text { Functionial } \\
\text { Flow Block } \\
\text { Diaglatms }\end{array}$ & $\begin{array}{l}3.2 .3 \text { Relerence } \\
\text { to Jinnctions and } \\
\text { Requirements } \\
\text { Procedure }\end{array}$ & $\begin{array}{l}\text { Requirements } \\
\text { Baseline }\end{array}$ & $\begin{array}{l}\text { Show system functional behavior by identilying individual } \\
\text { functions and their inter-relationships. They are used to } \\
\text { determine requited tumctions, for allecation of functions to } \\
\text { SSCS, for specitication gencration, aurd to support modeling. }\end{array}$ & $\begin{array}{l}\text { IINI-IP-08.12, } \\
\text { Volume IV, } \\
\text { Section } 3.2 \\
\text { (I.NIIC } 1997)\end{array}$ & Program Oftices & $\begin{array}{l}\text { The associated limclional } \\
\text { (kescriflions and } \\
\text { reyurtuments reside in } \\
\text { [IST!). }\end{array}$ \\
\hline $\begin{array}{l}\text { Recenirements } \\
\text { Anatysis } \\
\text { Reports }\end{array}$ & 3.2 .4 & $\begin{array}{l}\text { Requirements } \\
\text { Basclime }\end{array}$ & 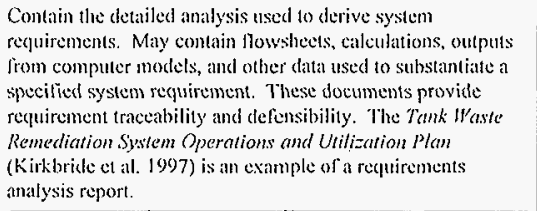 & None specified & $\begin{array}{l}\text { Program office } \\
\text { lor the require- } \\
\text { ments it } \\
\text { generates, } \\
\text { Projects } \\
\text { oherwise. }\end{array}$ & 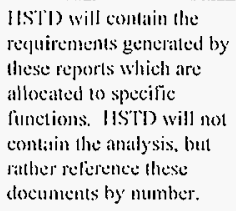 \\
\hline $\begin{array}{l}\text { System } \\
\text { Assessment } \\
\text { Reports }\end{array}$ & 3.2 .5 & $\begin{array}{l}\text { Requircments } \\
\text { I3ascline }\end{array}$ & 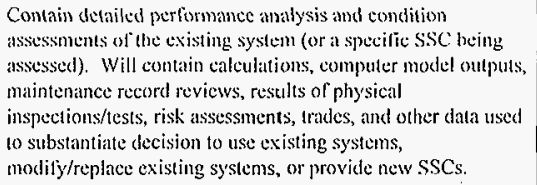 & Nome specified & $\left\{\begin{array}{l}\text { TWRS } \\
\text { Enginscring and } \\
\text { Nucleitt Salicty }\end{array}\right.$ & 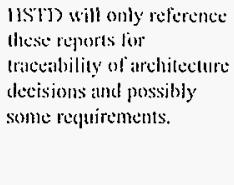 \\
\hline
\end{tabular}


Table 2.-Bascline Documents. (7 Sheets)

\begin{tabular}{|c|c|c|c|c|c|c|}
\hline Product & $\begin{array}{l}\text { SEMP process } \\
\text { reference } \\
\text { section }\end{array}$ & $\begin{array}{l}\text { Baseline } \\
\text { Category }\end{array}$ & Purpose/use & $\begin{array}{l}\text { Format/ } \\
\text { content/ } \\
\text { procedure }\end{array}$ & Responsibility & Rolationship to HSTD \\
\hline AGA R:ports & 3.2 .6 & $\begin{array}{l}\text { Requirements } \\
\text { [3aseline }\end{array}$ & $\begin{array}{l}\text { Contain detailed analysis of alternative technologies and } \\
\text { system configurations, evaluating each against a } \\
\text { predetermined set of decision criteria. Will contain } \\
\text { calculations, system layout relevant to the study, cost } \\
\text { analyses, and other types of analyses relevant to the decision } \\
\text { criteria sclected. May contain recommendations for the } \\
\text { prefered solution. This document will be used by the } \\
\text { decision board to select which technologies and system } \\
\text { configurations to develop futher. }\end{array}$ & $\begin{array}{l}\text { IINL-IP-08.1?, } \\
\text { Volume IV, } \\
\text { Section } 3.3 \\
\text { (LMHC 1997) }\end{array}$ & $\begin{array}{l}\text { Progrim Office } \\
\text { lor the SSCs it } \\
\text { specifies. } \\
\text { Projects } \\
\text { otherwise. }\end{array}$ & $\begin{array}{l}\text { ISTD will contain } \\
\text { poinlers to the stedy as } \\
\text { traceability for sysiem } \\
\text { atchilecture decisions } \\
\text { macle. Sfecilic results and } \\
\text { analysis will not to stored } \\
\text { in the IISTD. }\end{array}$ \\
\hline $\begin{array}{l}\text { Decision } \\
\text { Documents }\end{array}$ & $\begin{array}{l}2.3 .4,3.2 .6 \\
3.2 .11\end{array}$ & $\begin{array}{l}\text { Requirements } \\
\text { Baseline }\end{array}$ & $\begin{array}{l}\text { Identily the selected alternative based on an } \Lambda G \wedge \text {, system } \\
\text { assessment, or trade study. Will include rationale for the } \\
\text { decisions made. }\end{array}$ & $\begin{array}{l}\text { IINI-II'-0842, } \\
\text { Volume IV, } \\
\text { Section } 2.7 \\
\text { (I.MIIC 1997) }\end{array}$ & $\begin{array}{l}\text { Responsible } \\
\text { Manager }\end{array}$ & 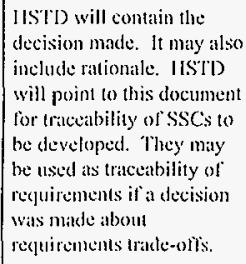 \\
\hline $\mathrm{ICD}$ : & 3.2 .8 & $\begin{array}{l}\text { Requirements } \\
\text { Baseline }\end{array}$ & $\begin{array}{l}\text { Contain requirements and agreenents about specific physical } \\
\text { inlerfaces between SSCS, including major lacilities. They } \\
\text { will repeat values called out in specifications and contain } \\
\text { drawing data when matturs. (They will NOT' specify } \\
\text { organizational interlaces.) These documents will be used to } \\
\text { manage interfaces between items in design and/or with } \\
\text { existing SSCs. Parties responsible for providing the } \\
\text { interfacing SSCS will be held accountable to the requirements } \\
\text { in the relevant ICD. }\end{array}$ & $\begin{array}{l}\text { TWRS ICD } \\
\text { Definition } \\
\text { Document } \\
\text { (Acres 1997) }\end{array}$ & $\begin{array}{l}\text { Program ortice } \\
\text { aud Projects is } \\
\text { needed } \\
\end{array}$ & 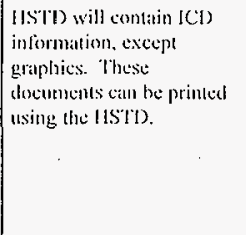 \\
\hline
\end{tabular}


Table 2.- Baseline Documents. (7 Sheets)

\begin{tabular}{|c|c|c|c|c|c|c|}
\hline Product & $\begin{array}{l}\text { SEMP process } \\
\text { reference } \\
\text { section }\end{array}$ & $\begin{array}{l}\text { Baseline } \\
\text { Category }\end{array}$ & Purpose/use & $\begin{array}{l}\text { Format/ } \\
\text { content/ } \\
\text { procedure }\end{array}$ & Responsibility & Relationship to ISTD \\
\hline $\begin{array}{l}\text { Specially } \\
\text { Pngincering } \\
\text { Amalysis } \\
\text { Reports }\end{array}$ & 3.2 .9 & $\begin{array}{l}\text { Requuirements } \\
\text { Baseline }\end{array}$ & $\begin{array}{l}\text { Contain analysis required to convert speciatty engineering } \\
\text { requirements into design requirements. May contain } \\
\text { calculations, outputs liom computer models, and other data } \\
\text { used to substantiate a specilied requirement. These } \\
\text { documents provide requirement traceability and defensibility. }\end{array}$ & None specilied & $\begin{array}{l}\text { TWRS } \\
\text { Fingineering and } \\
\text { Netelear Saltety } \\
\text { Envirommental, } \\
\text { Salety \& Ifualch } \\
\text { and Quality } \\
\text { Assurance }\end{array}$ & $\begin{array}{l}\text { IISID) will comtain } \\
\text { pointers to these reports } \\
\text { lor requiremems } \\
\text { (raceability. HISlD will } \\
\text { contain requirements } \\
\text { generated by these reports } \\
\text { as allocated to systems. }\end{array}$ \\
\hline $\begin{array}{l}\text { Level I } \\
\text { Specilications }\end{array}$ & 3.2 .10 & $\begin{array}{l}\text { Requirements } \\
\text { Bascline }\end{array}$ & $\begin{array}{l}\text { Contain system-level requirements for a specific major } \\
\text { facility. Requirenents include functions, performance levels, } \\
\text { time factors, system environments, RAM, safety, human } \\
\text { factors, logistics, and many others. Also contains a } \\
\text { requirements verification matrix that will be used to } \\
\text { determine the means of system design verification. These } \\
\text { documents proviche the basis for system assessment and } \\
\text { moteling. }\end{array}$ & $\begin{array}{l}\text { IINI -IP-0842, } \\
\text { Volume IV, } \\
\text { Seclion } 3.4 \\
\text { (IMIIC 1997) }\end{array}$ & P'rogram Olfice & $\begin{array}{l}\text { IISlO will contain } \\
\text { specilication information, } \\
\text { exeepl grapthics. These } \\
\text { documents will be printed } \\
\text { and managed using the } \\
\text { |1ST). }\end{array}$ \\
\hline $\begin{array}{l}\text { L.evel ? } \\
\text { Specificalions }\end{array}$ & 3.2 .10 & $\begin{array}{l}\text { Requirements } \\
\text { Basceline: }\end{array}$ & 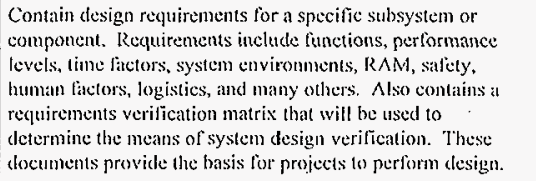 & $\begin{array}{l}\text { IINI:-IP-0842, } \\
\text { Volume IV, } \\
\text { Section } 3.14 \\
\text { (LMIIC 1997) }\end{array}$ & Program Olitice & $\begin{array}{l}\text { HSTD will contain } \\
\text { specification information, } \\
\text { excepl graphics. These } \\
\text { documents will be prinled } \\
\text { and managed using the } \\
\text { JIST). }\end{array}$ \\
\hline $\begin{array}{l}\text { Trakd Shuty } \\
\text { Report }\end{array}$ & 3.2 .11 & $\begin{array}{l}\text { Requirements } \\
\text { Bascline }\end{array}$ & $\begin{array}{l}\text { Contains analyses that trades requirements against a } \\
\text { predecermined set of criteria. These reports can look across a } \\
\text { latger view of the system to bring requirements into balanee. } \\
\text { May contain flowsheets, calculations, outputs from computer } \\
\text { models, and oller data used to substantiate a specilied system } \\
\text { requirement. These documents may feed a decision board } \\
\text { who will make changes to traded requirements. They provide } \\
\text { requirement traceability and defensibility when aceepted. }\end{array}$ & None specified & $\begin{array}{l}\text { TWRS } \\
\text { lingineering and } \\
\text { Nuclear Salety }\end{array}$ & 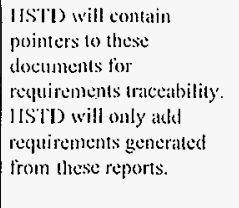 \\
\hline
\end{tabular}


Table 2-- Baseline Documents. (7 Sheets)

\begin{tabular}{|c|c|c|c|c|c|c|}
\hline Product & $\begin{array}{l}\text { SEMP process } \\
\text { reference } \\
\text { section }\end{array}$ & $\begin{array}{l}\text { Bascline } \\
\text { Category }\end{array}$ & Purpose/use & $\begin{array}{l}\text { Format/ } \\
\text { content/ } \\
\text { procedure }\end{array}$ & Responsibility & Relalionship to [STD \\
\hline $\begin{array}{l}\text { Project Design } \\
\text { Criteria } \\
\text { Doctment }\end{array}$ & 3.3 & $\begin{array}{l}\text { Reguirements } \\
\text { Basedine }\end{array}$ & $\begin{array}{l}\text { Delines project scope by identifying specilic SSCs the project } \\
\text { will develop and construct. It specifies the location and } \\
\text { identifies the points of interfice for each SSC with adjoining } \\
\text { systems. }\end{array}$ & None specilied & Program Olfice & $\begin{array}{l}\text { This dostument will not be } \\
\text { contained within the } \\
\text { HSTD. }\end{array}$ \\
\hline $\begin{array}{l}\text { Master } \\
\text { E.guipment } \\
\text { Lisit }\end{array}$ & $\begin{array}{l}3.4 \text { Reference to } \\
\text { lhe lingincering } \\
\text { Plas }\end{array}$ & $\begin{array}{l}\text { Design } \\
\text { l3asetine }\end{array}$ & $\begin{array}{l}\text { Identilies all the equipment items and associated design } \\
\text { drawings for a given SSC. This list can be at he major } \\
\text { facility level, subsystem, or component levels. Such a list at } \\
\text { the major facility level would identify SSCs composing that } \\
\text { facility. }\end{array}$ & $\begin{array}{l}\text { Sec Rifacy } 1998 \\
\text { and procedures }\end{array}$ & Projecl & $\begin{array}{l}\text { This document will not be } \\
\text { conlained within the } \\
\text { [ISI'D. }\end{array}$ \\
\hline $\begin{array}{l}\text { Design } \\
\text { 1) rawings }\end{array}$ & $\begin{array}{l}3.4 \text { Reference } 10 \\
\text { tle lingincering } \\
\text { Plan }\end{array}$ & $\begin{array}{l}\text { Design } \\
\text { I3aseline }\end{array}$ & $\begin{array}{l}\text { Specily the physical geonetry, material, and manulacturing } \\
\text { requirements for SSCs and the parts of which they are } \\
\text { composed. They are used for fabrication and construction of } \\
\text { SSCs and their parts. }\end{array}$ & $\begin{array}{l}\text { See Rifatey } 1998 \\
\text { and procedintes }\end{array}$ & Project & $\begin{array}{l}\text { This doctument will not be } \\
\text { comalimed within the } \\
\text { IISII). }\end{array}$ \\
\hline $\begin{array}{l}\text { Design } \\
\text { Analysis } \\
\text { Reports }\end{array}$ & $\begin{array}{l}3 .+ \text { Refirence to } \\
\text { the lingintering } \\
\text { Plan }\end{array}$ & $\begin{array}{l}\text { Design } \\
\text { Basclinc }\end{array}$ & $\begin{array}{l}\text { Document design calculations and other analyses that were } \\
\text { used to arrive at a given design. This document will be used } \\
\text { to provide traceability of design and may be used to } \\
\text { annlytically demonstrale how the design complics with the } \\
\text { specification. }\end{array}$ & $\begin{array}{l}\text { Sec Rilacy } 1998 \\
\text { and procedutes }\end{array}$ & Project & $\begin{array}{l}\text { This document will not be } \\
\text { contanined within the } \\
\text { itsil). }\end{array}$ \\
\hline $\begin{array}{l}\text { Requirements } \\
\text { Verilicalion } \\
\text { Retponts }\end{array}$ & $\begin{array}{l}3.4 \text { Reference to } \\
\text { dis lingincering } \\
\text { l'tum }\end{array}$ & $\begin{array}{l}\text { Design } \\
\text { Bascline }\end{array}$ & $\begin{array}{l}\text { Compile into a single source the evidence that a given SSC } \\
\text { design complies will the reguirements of the associated } \\
\text { design specification. Verification method, activities, and } \\
\text { results will be documented. Onen such a report will point to } \\
\text { series of Design Analy'sis Reports and Test Reponts to show } \\
\text { compliance. }\end{array}$ & $\begin{array}{l}\text { Sec Rifacy } 1908 \\
\text { and procedures }\end{array}$ & Project & $\begin{array}{l}\text { lhis document will not be } \\
\text { contained within the } \\
\text { JISI). }\end{array}$ \\
\hline $\begin{array}{l}\text { Tesi } \\
\text { Procedures }\end{array}$ & $\begin{array}{l}3.4 \text { Referwee } 10 \\
\text { lhe Engineering } \\
\text { Plan }\end{array}$ & $\begin{array}{l}\text { Design } \\
\text { Basctinc }\end{array}$ & $\begin{array}{l}\text { Document dle specilic SSC test procedures reguired to verify } \\
\text { SSC stitability at various stages of development. Reference } \\
\text { the SLMP, Section 3.5, lor the major test categories for which } \\
\text { this doctment is reguired. }\end{array}$ & $\begin{array}{l}\text { Sec Riliacy } 1998 \\
\text { and procedures }\end{array}$ & l'rọices & $\begin{array}{l}\text { This document will non be } \\
\text { contanued within the } \\
\text { IIsid). }\end{array}$ \\
\hline Test Reports & $\begin{array}{l}3.4 \text { Refurence } 10 \\
\text { the linginesring } \\
\text { l'lan }\end{array}$ & $\begin{array}{l}\text { Design } \\
\text { Basistinc }\end{array}$ & $\begin{array}{l}\text { Document the results of tests performed lor the purposes } \\
\text { listed in the Sl:MI', Section } 3.5 \text {. }\end{array}$ & $\begin{array}{l}\text { See Rilicy } 1998 \\
\text { and procedures }\end{array}$ & l'roject & 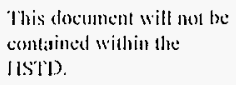 \\
\hline
\end{tabular}


HNF-SD-WM-SEMP-002 Rev 1

\begin{tabular}{|c|c|c|c|c|c|c|c|}
\hline 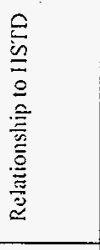 & 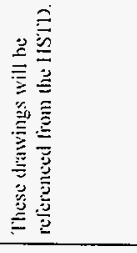 & 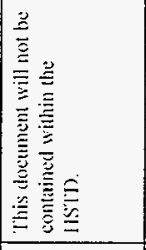 & 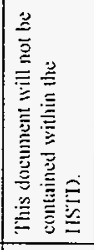 & 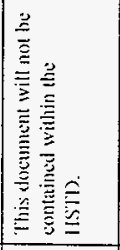 & 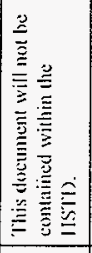 & 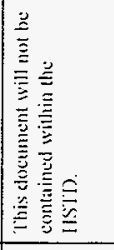 & 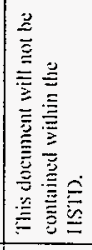 \\
\hline 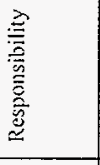 & $\frac{\overline{3}}{2}$ & \begin{tabular}{|l}
$\bar{y}$ \\
$\underline{2}$ \\
\end{tabular} & 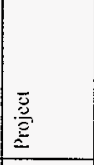 & \begin{tabular}{|l}
$\overline{3}$ \\
$\frac{\overline{3}}{2}$ \\
$\frac{2}{2}$
\end{tabular} & 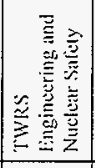 & 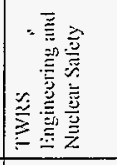 & 参 \\
\hline 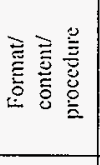 & 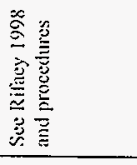 & 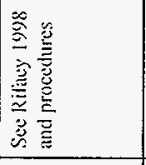 & 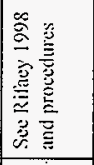 & 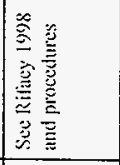 & 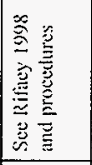 & 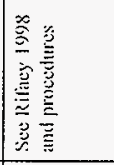 & 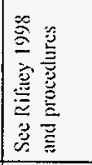 \\
\hline 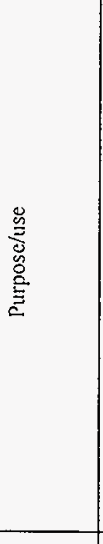 & 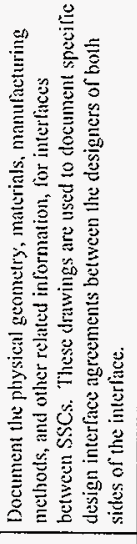 & 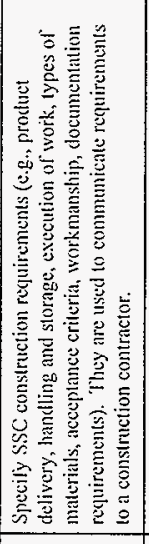 & 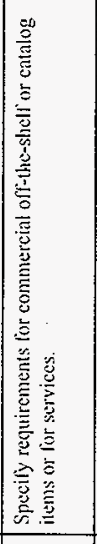 & 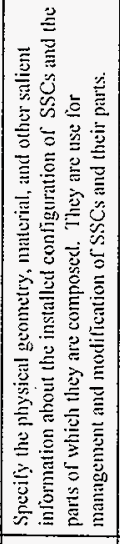 & 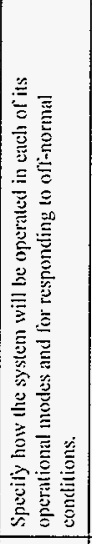 & 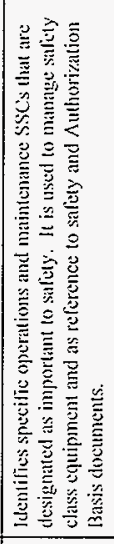 & 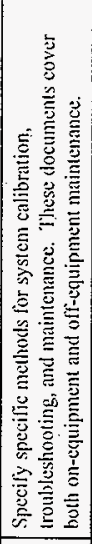 \\
\hline 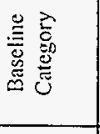 & 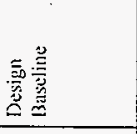 & 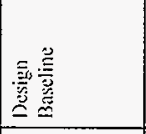 & 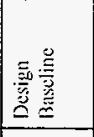 & 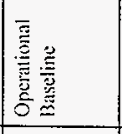 & 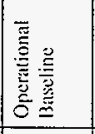 & 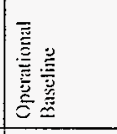 & 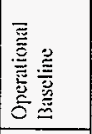 \\
\hline 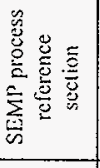 & 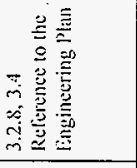 & 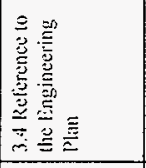 & 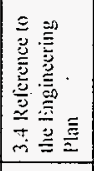 & 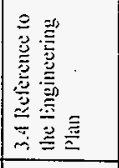 & 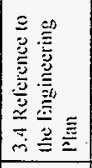 & 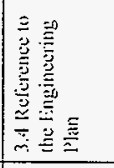 & 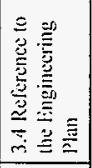 \\
\hline 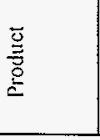 & 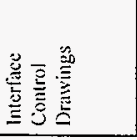 & 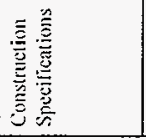 & 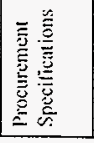 & 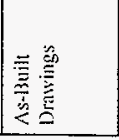 & 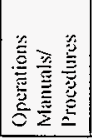 & 竧 & 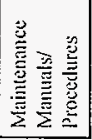 \\
\hline
\end{tabular}


HNF-SD-WM-SEMP-002 Rev 1

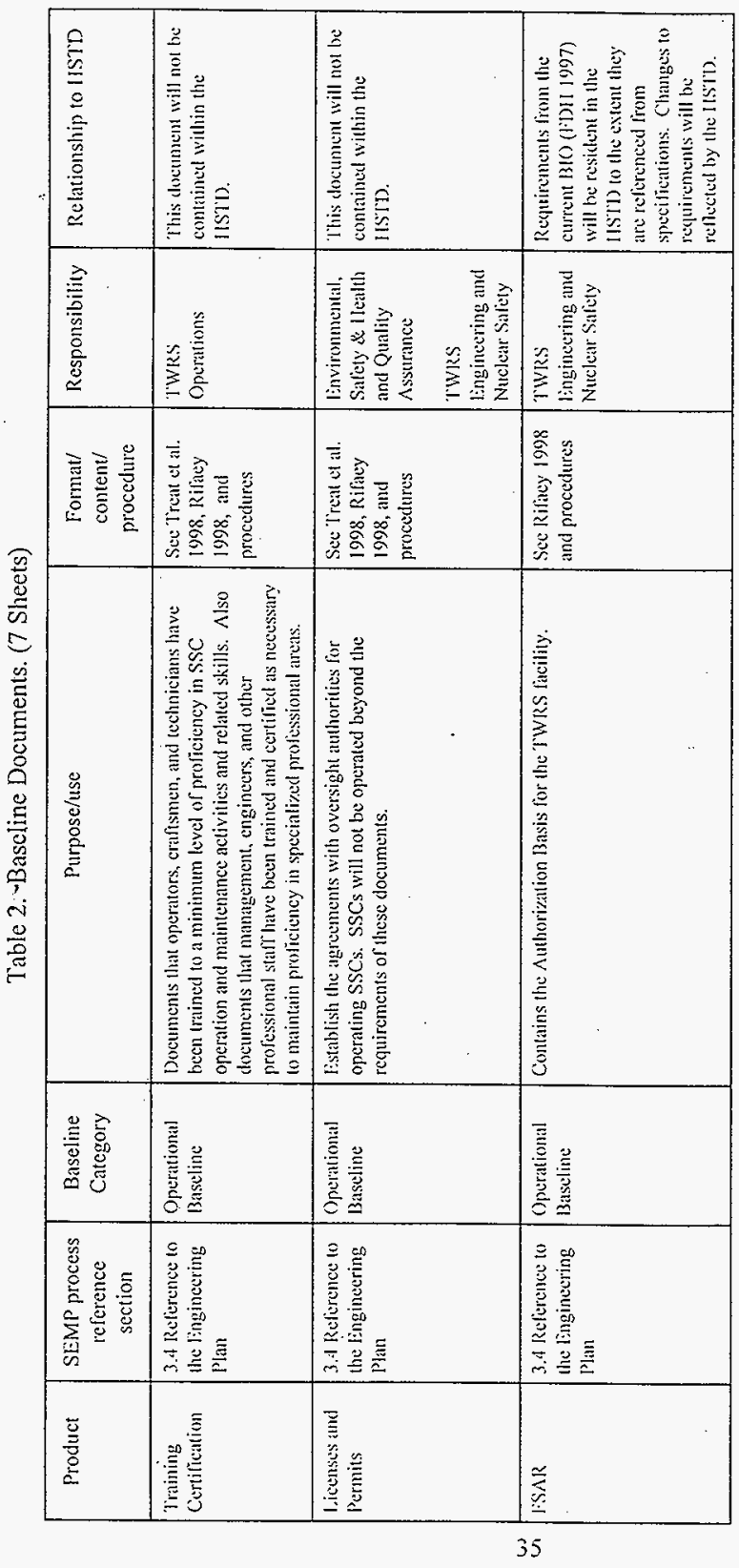


Table 2. - Baseline Documents. (7 Sheets)

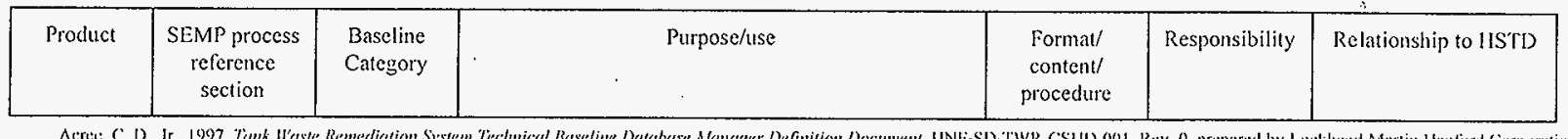

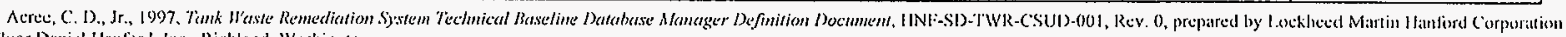
For Fituor Danicl tlantord, Jac., Richland. Washington.

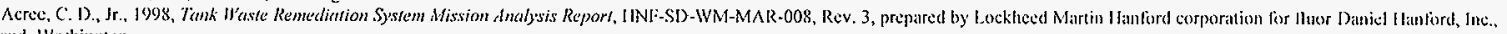

Richliand, Washingtous.

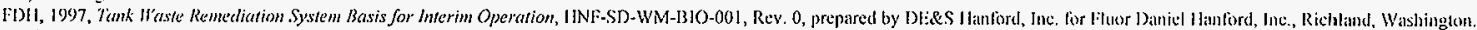

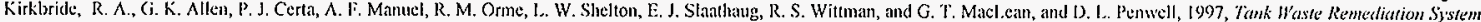

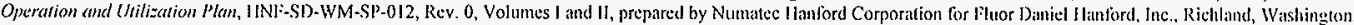

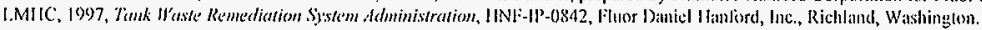

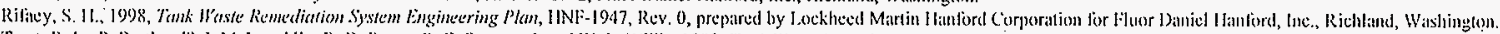

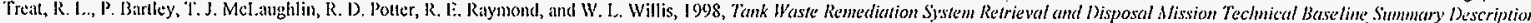

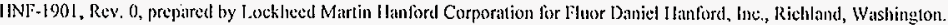

$\Lambda C A=$ altemative generation and antalysis.

$B \mid O=B$ assis for Itucrim Operations.

FSAR = linal Saticty An:alysis Report.

|IS|'D = Ilantord Sile Teclinical Baseline Database.
ICD $=$ Interfice Conirol Document.

$\mathrm{MAR}=$ Mission Analysis Ręport.

$O \& M=$ operations and maimenance.

$\mathrm{RAM}=$ Reliability, $A$ vailability, and Maintainability.
SiMP] - Systems [angincering Minagement Plat

SSC = struclure, system, and compontint.

TWRS = Tank Waste Remedialion System. 


\subsection{INTEGRATED LOGISTICS SUPPORT}

This discipline will determine what is needed to support system operations and maintenance. This evaluation will be performed for each major facility and SSC. Since it is important to deliver waste on time to the vendors, logistics support evaluation will consider the entire system, not just for those SSCs being developed. An integrated logistics support plan will be generated for applicable major facilities during requirements development. Support concepts will be generated for new and modified SSCs during the project conceptual design phase.

A logistics support plan will be generated for each new and modified SSC during the project design phase. Each of these plans will consider the TWRS operations and maintenance concept document; reliability, availability, and maintainability requirements; and the existing support infrastructure.

Results of this planning will be used as a starting point for the logistics support analysis, which will be performed during design development. This analysis will address the following areas:

- Staffing requirements for operations and maintenance

- Maintenance requirements

- Support equipment needs

- $\quad$ Supply support (spares)

- Technical data requirements for operations and maintenance

- Training requirements for operations and maintenance

- Computer resources required to support maintenance and logistics databases

- Additional maintenance facility requirements

- Packaging, handling, storage, and transportation requirements for SSCs and spares.

This activity will evolve to target daily schedules/plans to meet feed delivery, storage and disposal, and eventually closure to meet mission milestones. 


\subsection{GLOSSARY}

Architecture. The physical SSCs selected to perform the TWRS Project. Architecture is selected through an analysis of alternative solutions, selecting the design approach that best meets decision criteria.

Baseline, Integrated. A baseline composed of the program's technical, work scope, schedule, and cost baselines. Used as a basis to measure design, cost, and schedule change impacts.

Baseline, Technical. The set of equipment, facilities, materials, qualified staff, and documentation necessary to perform the TWRS Project within specified requirements. The Technical Baseline matures over the life cycle of the development effort from (1) the requirements baseline (the technical requirements and interface definitions); (2) the design baseline (design analyses, design drawings, and verification analyses/test reports); to ( 3 ) the operational baseline (actual operating hardware/software, supporting manuals/procedures; trained operational staff, and as-built drawings).

Constraint. An externally imposed mandatory restriction, limitation, or requirement imposed by agencies and organizations (e.g., the U.S. Congress, U.S. Environmental Protection Agency, Washington State Department of Ecology, and other regulatory agencies) and DOE Orders, Secretarial Notices, and other regulatory documents. Where necessary, these constraints will be interpreted to derive performance requirements that are quantified and verifiable.

Design Requirements. The "build to" and "buy to" requirements for products and "how to execute" requirements for processes. Design requirements are developed through synthesis of detailed performance requirements, engineering standards, and design concepts.

Function. A specific task, action, activity, or process that supports the achievement of an objective (e.g., an operation that a system must perform to accomplish its mission).

Interface Control Documents (ICDs). A document representing a design agreement between interfacing hardware or software systems which fully defines the interface. An ICD is placed under Configuration Control and is considered part of the baseline.

Interface Requirement. A necessary function input that is defined at the system boundary across which material, data, or energy passes.

Major Facility. Refers to the top-level architecture defined by Hanford Site Systems Engineering. The Hanford Site architecture is divided into a set of Major Facilities (nine of which belong under the TWRS Project). The TWRS structures and components exist as subindentures to the major facilities. 
Performance Requirement. The extent to which a mission or function must be executed; generally measured in terms of quantity, quality, coverage, timeliness, or readiness. Performance requirements are initially defined through requirements analyses and trade studies using mission need, objective, and/or requirement statements. Performance requirements are assigned to lowerlecel system functions through top-down allocation and are assigned to programs, program elements, and projects through synthesis.

Program. This refers to TWRS organization that is financially responsible for major mission elements and establishes strategy.

Project. This refers to the discrete work within the larger TWRS Project that has firmly established objectives (deliverables); budget (cost); and scheduled beginning, intermediate, and ending date milestones. A unique subset are line items that have constraints due to capital funding and reporting requirements to the U.S. Congress.

Review Authority. The DOE counterpart to TWRS contractor who is charged with DOE Order 430.1 Critical Decision responsibility.

Specification. (1) A document prepared to support acquisition and life-cycle management that clearly and accurately describes essential technical requirements and verification procedures for items, materials, and services. (2) A statement of a set of requirements to be satisfied by a product, material, or process indicating, whenever appropriate, the procedure by which it may be determined whether the requirements given are satisfied.

Specification, Level 1. Level 1 specifications are system-level specifications written for the TWRS major facilities. They are used to provide a consistent source for performance requirements and constraints.

Specification, Level 2. Level 2 specifications are used as the "design-to" specification for specific end items that are being developed/designed.

Specification Tree. The hierarchical depiction of the specifications needed (planned or existing) for the TWRS systems development.

Synthesis. The translation of functions and requirements into possible integrated solutions (resources and techniques) satisfying basic input requirements. System element alternatives that satisfy allocated performance requirements are generated; preferred system element solutions that satisfy internal and external physical interfaces are selected; system concepts, preliminary designs, and detailed designs are completed as a function of the development phase; and system elements are integrated into a physical architecture.

Systems, Structures, and Components (SSC). This term refers to elements that comprise the total operating system. It does not imply any particular indenture, but rather is used as a general term for elements. Safety SSCs are a subset of these SSCs. 
Systems Engineering. A comprehensive, iterative problem-solving process that is used to (1) transform validated DOE needs and requirements into a life-cycle balanced solution set of system product and process designs, (2) generate information for decision makers, (3) integrate to optimize and (4) provide information for the next program phase. The problem-solving process and success criteria are defined through requirements analysis, functional analysis, and systems analysis and control. Alternative solutions, evaluation of those alternatives, selection of the best life-cycle balanced solution, and the description of the solution through the design package are accomplished through transitioning from a functional concept to a physical concept using systems analysis and modeling techniques.

Systems Engineering Management. Organizing and directing tasks, activities, and performances related to the Technical Baseline work, defining the Systems Engineering process, ensuring that the process is followed, reviewing technical results, and making strategic technical decisions based on those results for the system under development.

Technical Performance Measurement. The assessment process that estimates and tracks essential technical parameters to provide visibility of actual versus planned performance, provide early detection and prediction of problems, and support assessment of the impact of proposed changes.

Test and Evaluation. The complete set of activities that verify that end products meet customer requirements. Test and Evaluation includes (1) reviews and analysis performed during the design process; (2) inspection activities during manufacturing and construction; and (3) testing performed during design, manufacturing, construction, turnover activities, TWRS Project management planning, operation and maintenance of storage tanks, waste retrieval, separation, immobilization (private contractors), storage disposal, and closure.

Validation. (1) An assessment to verify system requirements will satisfy mission objectives. (2) A demonstration that a predictive model and its mathematical expression adequately reflect reality. Validation usually consists of comparing the results of the applied mathematical expression to measured results from the system being modeled (or from similar or identical systems) and showing that any differences were expected and/or within acceptable error.

Verification. The act of determining and documenting whether items, activities, processes, services, or documents conform to specified constraints, requirements, or commitments. This process is performed at each level of system architecture development (i.e., from hardware item components through the system level). The method used to show compliance (test, inspection, demonstration, or analysis) is dependent on architecture complexity, engineering test data availability, and validated analytical methods availability or existence. 


\subsection{REFERENCES}

\section{Database}

HSTD, n.d., Hanford Site Technical Baseline Database, database maintained by Lockheed Martin Hanford Corporation for Fluor Daniel Hanford, Inc., Richland, Washington.

\section{Federal Register}

62 FR 8693; 1997, "Record of Decision for the Tank Waste Remediation System, Hanford Site, Richland, WA" Federal Register, Vol. 62, pp. 8693-8704 (February 26).

\section{Good Practice Guides}

GPG-FM-002, Critical Decision Criteria, Life Cycle Asset Management, Good Practice Guide, U.S. Department of Energy, Washington, D.C.

GPG-FM-010, Project Execution and Engineering Management Planning, Life Cycle Asset Management, Good Practice Guide, U.S. Department of Energy, Washington, D.C.

GPG-FM-015, Project Review's, Life Cycle Asset Management, Good Practice Guide, U.S. Department of Energy, Washington, D.C.

,

\section{U.S. Department of Energy Orders}

DOE Order 430.1, Life Cycle Asset Management, U.S. Department of Energy, Washington, D.C. DOE Order 4700.1, Project Management System, U.S. Department of Energy, Washington, D.C.

\section{Documents}

Acree, C. D., Jr., 1997, Tank Waste Remediation System Technical Baseline Database Manager Definition Document. HNF-SD-TWR-CSUD-001, Rev. 0, prepared by Lockheed Martin Hanford Corporation, Richland, Washington.

Acree, C. D., Jr., 1998, Tank Waste Remediation System Mission Analysis Report, HNF-SD-WM-MAR-008, Rev. 3, prepared by Lockheed Martin Hanford Corporation for Fluor Daniel Hanford, Inc, Richland, Washington. 
DOE, 1996, Draft Hanford Remedial Action Environmental Impact Statement and Comprehensive Land L'se Plan, DOE/EIS-0222D, U.S. Department of Energy, Washington, D.C.

Ecology, EPA, and DOE, 1996, Hanford Federal Facility Agreement and Consent Order, 2 vols., Washington State Department of Ecology, U.S. Environmental Protection Agency, and U.S. Department of Energy, Olympia, Washington.

EIA, 1994, EIA Engineering Standard Systems Engineering, IS-632, Electronic Industries Association, Arlington, Virginia.

FDH, 1996, Subcontract between Fluor Daniel Hanford, Inc., and Lockheed Martin Hanford Corporation, Contract 80232764-9-K1001, Fluor Daniel Hanford, Inc., Richland, Washington.

FDH, 1997a, Project Hanford Management Contract Management and Integration Plan, HNF-MP-001, Rev. 1, Fluor Daniel Hanford, Inc., Richland, Washington.

FDH, 1997b, Tank Waste Remediation System Basis for Interim Operation, HNF-SD-WM-BIO-001, Rev. 0, prepared by DE\&S Hanford, Inc., for Fluor Daniel Hanford, Inc., Richland, Washington.

Freeman, D. V., 1998, Tank Waste Remediation System Program Plan, HNF-1883, Rev. 1, prepared by Lockheed Martin Hanford Corporation for Fluor Daniel Hanford, Inc., Richland, Washington.

Kirkbride, R.A., G. K. Allen, P. J. Certa, A. F. Manuel, R. M. Orme, L. W. Shelton, E. J. Slaathaug, R. S. Wittman, and G. T. MacLean, and D. L. Penwell, 1997, Tank Waste Remediation System Operation and Utilization Plan, HNF-SD-WM-SP-012, Rev. 0, Volumes I and II, prepared by Numatec Hanford Corporation for Fluor Daniel Hanford, Inc., Richland, Washington.

Lee, A. K., 1997, Hanford Site Cleanup Interface Control Document Matrix, HNF-SD-WM-SDS-007, Rey. 0, Fluor Daniel Hanford, Inc., Richland, Washington.

LMHC, 1997, TWRS Administration, HNF-IP-0842, prepared by Lockheed Martin Hanford Corporation for Fluor Daniel Hanford, Inc., Richland, Washington.

Peck, L. G., 1998, Tank Waste Remediation System Test and Evaluation Plan, HNF-2029. Rev. 0, prepared by Lockheed Martin Hanford Corporation for Fluor Daniel Hanford, Inc., Richland, Washington. 
Rifaey, S. H., 1998, Tank Waste Remediation System Engineering Plan, FNF-1947, Rev. 0, prepared by Lockheed Martin Hanford Corporation for Fluor Daniel Hanford, Inc.. Richland, Washington.

RL; 1996a, Honford Strategic Plan, DOE/RI 96-92, Rev. O, U.S. Department of Energy, Richland Operations Office, Richland, Washington.

RL, 1996b, Project Hanford Wanagement Contract (PHMC), DE-AC06-96RL13200, U.S. Department of Energy, Richland Operations Office, Richland, Washington.

RL, 1997, Tank Waste Remediation System Systems Engineering Management Policy, 97-MSD-193, U.S. Department of Energy, Richland Operations Office, Richland, Washington.

Treat, R. L., P. Bartley, T. J. McLaughlin, R. D. Potter, R. E. Raymond, and W. L. Willis, 1998, Tank Waste Remediation System Retrieval and Disposal Mission Technical Baseline Summary Description, HNF-1901, Rev. 0, prepared by Lockheed Martin Hanford Corporation for Fluor Daniel Hanford, Inc., Richland, Washington.

Vann, J. M., E. R. Hamm, and R. D. Crisp, 1998, Tank Waste Remediation System Configuration Management Plan, HNF-1900, Rev. 0, prepared by Lockheed Martin Hanford Corporation for Fluor Daniel Hanford, Inc., Richland, Washington.

Zimmerman, B. D., 1998, Tank Waste Remediation System Risk Management Plan, HNF-SD-WM-PMP-018, Rev. 2, prepared by Lockheed Martin Hanford Corporation for Fluor Daniel Hanford, Inc., Richland, Washington. 
HNF-SD-WM-SEMP-002 Rev 1

This page intentionally left blank. 
HNF-SD-WM-SEMP-002 Rev 1

\section{APPENDIX A}

\section{GUIDANCE AND REQUIREMENTS TO DELIVERABLES CROSSWALK}

\section{TWRS System Engineering \\ Management Plan}


HNF-SD-WM-SEMP-002 Rev 1

This page intentionally left blank. 
Table A-1. Guidance and Requirements to Deliverables Crosswalk TWRS System Engineering Management Plan.

\begin{tabular}{|c|c|c|}
\hline Guidance or Requirement & Status & Implementing Location \\
\hline $\begin{array}{l}\text { A.1 DOE Letter to H. J. Hatch, FDH, from W. J. } \\
\text { Taylor, DOE, dated August 8, 1997, \#9757162A } \\
\text { (36 ITEM CHECKLIST) }\end{array}$ & & \\
\hline $\begin{array}{l}\text { 1. TWRS mission analysis is complete and } \\
\text { consistent with higher level plans and specifications. }\end{array}$ & I & $\begin{array}{l}\text { Figure } 2 \text { and Section } 3.2 .1 \text { indicate the } \\
\text { MAR is based on higher level } \\
\text { plans/specifications and establishes the } \\
\text { basis for further requirements } \\
\text { development }\end{array}$ \\
\hline $\begin{array}{l}\text { 2. Requirements are identified, validated, and } \\
\text { documented. }\end{array}$ & 1 & $\begin{array}{l}2.3 .5 \text { - requirements traceability; } 3.2 . x- \\
\text { focuses on the development, validation } \\
\text { and documentation of sound } \\
\text { requirements }\end{array}$ \\
\hline 3. Requirements are allocated to functions. & 1 & $\begin{array}{l}\text { 3.2.3-functional analysis; } 3.2 .7 \text { - } \\
\text { requirements allocation }\end{array}$ \\
\hline $\begin{array}{l}\text { 5. Architecture is defined based upon analyses of the } \\
\text { mission and the functions and requirements. }\end{array}$ & 1 & $\begin{array}{l}\text { 3.2.X - SE process outlines approach for } \\
\text { establishing TWRS architecture }\end{array}$ \\
\hline $\begin{array}{l}\text { 6. All enabling assumptions have been formally } \\
\text { documented. Assumptions which have been } \\
\text { replaced with facts or decisions have been changed } \\
\text { in requirements documentation. } \\
\text { ? }\end{array}$ & 1 & $\begin{array}{l}\text { 2.3.5 - Requirements traceability } \\
\text { establishes format and structure of } \\
\text { issues, enabling assumptions, required } \\
\text { analyses, etc.; 3.2.x-SE process and } \\
\text { procedures referenced in SEMP, provide } \\
\text { guidance for establishing issues, } \\
\text { enabling assumption, required analyses } \\
\text { and documenting in RDD-100 }\end{array}$ \\
\hline $\begin{array}{l}\text { 9. System boundaries and interfaces with other } \\
\text { organizations and programs/projects are defined. }\end{array}$ & I & $\begin{array}{l}2.3 .2 \text { - Interface management - } \\
\text { establishes the requirement to manage } \\
\text { interfaces (boundaries); } 3.2 .8 \text { - interface } \\
\text { analysis }\end{array}$ \\
\hline $\begin{array}{l}\text { 10. Interface control documents have been prepared, } \\
\text { DOE comments have been resolved, issues have } \\
\text { been addressed, and approved interfaces are } \\
\text { managed. }\end{array}$ & I & $\begin{array}{l}\text { 2.3.2 - Interface management establishes } \\
\text { requirement to develop ICDs: } 3.2 .8 \text { - } \\
\text { interface analyses }\end{array}$ \\
\hline $\begin{array}{l}\text { 15. Technical risks have been identified and are } \\
\text { being managed. }\end{array}$ & I & $\begin{array}{l}2.3 .3 \text {-establishes requirement to identify, } \\
\text { assess, and manage risk; } 3.2 .6 \text {-identifies } \\
\text { risk as a parameter in alternative } \\
\text { evaluation/selection }\end{array}$ \\
\hline
\end{tabular}


Table A-1. Guidance and Requirements to Deliverables Crosswalk TWRS System Engineering Management Plan.

\begin{tabular}{l}
\multicolumn{1}{|c|}{ Guidance or Requirement } \\
\hline $\begin{array}{l}\text { 16. The.technical baseline is complete and } \\
\text { defensible, and represents best value to the } \\
\text { government. }\end{array}$
\end{tabular}
government.

17. The technical baseline under configuration control.

18. System reliability, availability, and maintainability have been assessed and are sufficient to support processing rate requirements.
19. The physical integrity of existing systems, structures, and components has been verified.

\section{The ability of the PHMC team to support} alternatives other than the baseline has been evaluated from a technical perspective.

29. The ability to support alternatives other than the baseline has been evaluated from a programmatic perspective.
Implementing Location

2. l-identifies the technical baseline as

part of integrated baseline.2.3.1-requires

baseline configuration management;

Figure 2-illustrates relationship of : technical baseline to other elements of

program; $3 . X$-focuses on development and control of defensible technical baseline

2.3.1-configuration management

I 3.2.11-identifies RAM as part of optimization process; 3.2.10-procedure establishes process for developing RAM requirements.; 3.2.9-integrates specialty engineers (e.g., RAM) in requirements development process; 3.7-establishes requirement for RAM considerations in logistics support requirements development

1 3.2.5-establishes requirement for evaluation/assessment of existing system integrity as part of architecture selection process.

I 3.2 .6 - The process for performing technical alternative analyses as the means of selecting from alternatives is outlined. Reference is made to the procedure for "Alternative Generation and Analysis" in HNF-IP-0842, Vol. IV, Section 3.3

$\begin{array}{ll}\text { I } & 3.2 .6 \text { - Performing alternative analyses to }\end{array}$ select from alternatives is outlined; Referenced the procedure for AGA in HNF-IP-0842, Vol. IV, Section 3.3; 3.2.11 - The process for "design optimization" is outlined with reference to performing necessary trade studies to optimized the design solution. 
Table A-1. Guidance and Requirements to Deliverables Crosswalk TWRS System Engineering Management Plan.

\begin{tabular}{|c|c|c|}
\hline Guidance or Requirement & Status & Implementing Location \\
\hline $\begin{array}{l}\text { 30. Management systems are in place to track and } \\
\text { report cost, schedule, and technical performance and } \\
\text { take appropriate corrective actions. }\end{array}$ & I & $\begin{array}{l}\text { 2.1-indicates integrated (cost, schedule, } \\
\text { technical) baseline will be tracked; } 2.3 .7 \text { - } \\
\text { establishes requirement to identify and } \\
\text { track technical performance. }\end{array}$ \\
\hline $\begin{array}{l}\text { 34. A records management program, including } \\
\text { technical drawings, has been implemented. }\end{array}$ & $I$ & $\begin{array}{l}\text { 2.3.1-establishes requirement to perform } \\
\text { configuration management of baseline } \\
\text { (e.g. specs, drawings, etc) }\end{array}$ \\
\hline $\begin{array}{l}\text { 35. A risk and decision management program has } \\
\text { been implemented at all levels. }\end{array}$ & 1 & $\begin{array}{l}\text { 2.3.3-establishes requirement for risk } \\
\text { management; } 2.3 .4 \text {-establishes } \\
\text { requirement for decision management }\end{array}$ \\
\hline $\begin{array}{l}\text { A.2 DOE Letter to H. J. Hatch, FDH, from W. J. } \\
\text { Taylor, DOE, dated August 8, 1997, \#9757162A } \\
\text { (BODY OF TEXT) }\end{array}$ & $\because$ & \\
\hline \multicolumn{3}{|l|}{$\begin{array}{l}\text { General PHMC Responsibilities from RL's } 8 / 8 / 97 \\
\text { letter, Section } 2.1\end{array}$} \\
\hline $\begin{array}{l}\text { 1. Establish a sound technical baseline including } \\
\text { ICDs }\end{array}$ & I & $\begin{array}{l}\text { 2.1-Relates the technical baseline to the } \\
\text { integrated baseline; 3.0-Identifies } \\
\text { process for establishing sound technical } \\
\text { baseline; 3.2.x-details process steps for } \\
\text { developing baseline; } 2.3 .2 \text {-establishes } \\
\text { requirement to manage interfaces; } 3.2 .8 \text { - } \\
\text { establishes process for analyzing } \\
\text { interface }\end{array}$ \\
\hline $\begin{array}{l}\text { 7. The technical and programmatic baselines are } \\
\text { under configuration management }\end{array}$ & I & $\begin{array}{l}\text { 2.3.1-establishes the requirement to } \\
\text { manage the system configuration and } \\
\text { indicates the process is applicable to the } \\
\text { technical and programmatic baselines. }\end{array}$ \\
\hline $\begin{array}{l}\text { 8. Management systems and program controls are } \\
\text { established }\end{array}$ & I & $\begin{array}{l}\text { 2.3.x-establishes the system using } \\
\text { disciplined approaches including: } 2.3 .1 \text { - } \\
\text { CM; } 2.3 .2 \text { - interface management; } 2.3 .3 \text { - } \\
\text { risk management; } 2.3 .4 \text { - decision } \\
\text { management; } 2.3 .5 \text { - technical } \\
\text { requirements; Traceability; } 2.3 .6 \text { - } \\
\text { technical reviews; } 2.3 .7 \text { - technical } \\
\text { performance measurement }\end{array}$ \\
\hline
\end{tabular}


Table A-1. Guidance and Requirenents to Deliverables Crosswalk TWRS System Engineering Management Plan.

\begin{tabular}{|c|c|c|}
\hline Guidance or Requirement & Status & Implementing Location \\
\hline $\begin{array}{l}\text { 9. A risk management program exists and includes } \\
\text { evaluation of performance and reporting of that } \\
\text { performance to DOE }\end{array}$ & I & $\begin{array}{l}\text { 2.3.j-establishes the requirement to } \\
\text { manage risk: } 3.2 .6 \text {-establishes the } \\
\text { process for evaluating and selecting } \\
\text { alternative solution. Selection process } \\
\text { includes evaluation of risk in the } \\
\text { analysis. }\end{array}$ \\
\hline $\begin{array}{l}\text { A.3 DOE Letter H. J. Hatch, FDH, from William } \\
\text { J. Taylor, DOE, dated December 2, 1997, } \\
\text { \#9761291 }\end{array}$ & . & \\
\hline $\begin{array}{l}\text { 3. Identify the specific requirements from DOE O } \\
425.1 \text { and } O 430.1 \text { against which readiness will be } \\
\text { assessed. (See also Section B.1 and B.2 of this table) }\end{array}$ & I & $\begin{array}{l}\text { While } 430.1 \text { is not imposed by RL on the } \\
\text { PHMC contract, the SEVP indicates that } \\
430.1 \text { will be used as guidance for } \\
\text { developing the TWRS system. Specific } \\
\text { requirements of } 425.1 \text { are not addressed } \\
\text { in SEMP. }\end{array}$ \\
\hline $\begin{array}{l}\text { 5. Provide specific information to address the ten } \\
\text { areas in Paragraph } 4.2 .4 \text { of the August } 8 \text { DOE letter } \\
\text { of direction }\end{array}$ & . & \\
\hline $\begin{array}{l}\text { h. Deliver to DOE or make available for DOE } \\
\text { review, a SEMP }\end{array}$ & $\mathrm{I}$ & HNF-SD-WM-SEMP-002, Rev. 2 \\
\hline $\begin{array}{l}\text { j. Deliver to DOE or make available for DOE } \\
\text { review, Draft Program Plans }\end{array}$ & I & $\begin{array}{l}\text { Figure } 2 \text { identifies the TWRS Program } \\
\text { Plan as a document providing input to } \\
\text { TWRS implementing plans like this } \\
\text { SEMP. }\end{array}$ \\
\hline $\begin{array}{l}\text { B.1 DOE Order 430.1,"Good Practice Guide," } \\
\text { GPG-FM-002 }\end{array}$ & $\therefore$ & \\
\hline 2.2.3 Baseline: Workscope (technical) Criteria & . & \\
\hline 1. Systems Engineering & 1 & Entire SEMP \\
\hline \multicolumn{3}{|l|}{ 2.2.4 Baseline: Cost Criteria } \\
\hline 2. Life Cycle Cost (LCC) & I & $\begin{array}{l}\text { 3.2.11-establishes "life cycle cost" as a } \\
\text { parameter to be considered in the design } \\
\text { optimization analysis. }\end{array}$ \\
\hline 2.2.7 Project Risk Criteria & & \\
\hline
\end{tabular}


Table A-1. Guidance and Requirements to Deliverables Crosswalk TWRS System Engineering Management Plan.

\begin{tabular}{|c|c|c|}
\hline Guidance or Requirement & Status & Implementing Location \\
\hline 1. Risk.Assessment & 1 & $\begin{array}{l}\text { 2.3.3-establishes the requirement for risk } \\
\text { management which includes "risk } \\
\text { assessment"; } 3.2 .6 \text {-establishes risk as a } \\
\text { parameter to be considered in evalnation } \\
\text { and selection of design alternatives. }\end{array}$ \\
\hline \multicolumn{3}{|l|}{ 2.3.7 Project Risk Criteria } \\
\hline 1. Risk Assessment & I & $\begin{array}{l}\text { 2.3.3-establishes the requirement for risk } \\
\text { management which includes "risk } \\
\text { assessment"; 3.2.6-establishes risk as a } \\
\text { parameter to be considered in evaluation } \\
\text { and selection of design alternatives. }\end{array}$ \\
\hline 2. Risk Management & I & $\begin{array}{l}\text { 2.3.3-establishes the requirement for risk } \\
\text { management. }\end{array}$ \\
\hline \multicolumn{3}{|l|}{ 2.3.9 Project Management Criteria } \\
\hline 2. Baseline Change Control & 1 & $\begin{array}{l}\text { 2.3.1-establishes requirement to manage } \\
\text { configuration; 2.3.2-establishes } \\
\text { requirement to manage interfaces; } 2.3 .5 \text { - } \\
\text { establishes requirement to provide } \\
\text { requirements traceability }\end{array}$ \\
\hline 4. Configuration Management & I & $\begin{array}{l}\text { 2.3.1-establishes requirement to manage } \\
\text { configuration }\end{array}$ \\
\hline \multicolumn{3}{|l|}{ 2.4.3 Work Scope (Technical) Criteria } \\
\hline $\begin{array}{l}\text { 1. Performance measures (see Contracting } \\
\text { Options/Acquisition Resource Planning/Application } \\
\text { of Performance Measures, GPG-FM-020). }\end{array}$ & 1 & $\begin{array}{l}\text { 2.3.7-establishes the requirement to } \\
\text { establish and track progress of technical } \\
\text { performance measures. }\end{array}$ \\
\hline 2.4.7 Project Risk Criteria & . & \\
\hline 1. Risk Assessment & I & $\begin{array}{l}\text { 2.3.3-establishes the requirement for risk } \\
\text { management which includes "risk } \\
\text { assessment"; 3.2.6-establishes risk as a } \\
\text { parameter to be considered in evaluation } \\
\text { and selection of design alternatives. }\end{array}$ \\
\hline 2. Risk Management & I & $\begin{array}{l}\text { 2.3.3-establishes the requirement for risk } \\
\text { management }\end{array}$ \\
\hline 2.4.9 Project Manas & & \\
\hline
\end{tabular}


Table A-1. Guidance and Requirements to Deliverables Crosswalk TWRS System Engineering Management Plan.

\begin{tabular}{|c|c|c|}
\hline Guidance or Requirement & Status & Implementing Location \\
\hline 2. Baseline Change Control & I & $\begin{array}{l}\text { 2.3.1-establishes requirement to manage } \\
\text { configuration; } 2.3 .2 \text {-establishes } \\
\text { requirement to manage interfaces; } 2.3 .5 \text { - } \\
\text { establishes requirement to provide } \\
\text { requirements traceability }\end{array}$ \\
\hline 4. Configuration Management & $\bar{I}$ & $\begin{array}{l}\text { 2.3.1-establishes requirement to manage } \\
\text { configuration }\end{array}$ \\
\hline 2.5.3 Baseline Workscope Technical Criteria & I & Entire Document \\
\hline 2.5.9 Project Management & . & \\
\hline 1. Configuration Management & $\overline{\mathrm{I}}$ & $\begin{array}{l}\text { 2.3.1-establishes requirement to manage } \\
\text { configuration }\end{array}$ \\
\hline $\begin{array}{l}\text { B.2 DOE Order 425.1, "Start-Up and Restart of } \\
\text { Nuclear Facilities," Section 4.d.(1)-(20) }\end{array}$ & $\therefore$ & \\
\hline $\begin{array}{l}425.1 \text { Core Requirement (7) - DOE Order } \\
\text { Conformance }\end{array}$ & $\mathrm{I}$ & $\begin{array}{l}\text { 3.2.x-identifies process to establish } \\
\text { defensible requirements; } 2.3 .5- \\
\text { establishes requirement to trace } \\
\text { requirement to laws, regulations, } \\
\text { (including DOE Orders); } 3.5 \text {-establishes } \\
\text { requirement to verify system meets } \\
\text { requirements }\end{array}$ \\
\hline 425.1, Core Requirement (10) - Startup Test Program & $\bar{I}$ & $\begin{array}{l}\text { 3.5-establishes requirement to develop a } \\
\text { test and evaluation process applicable to } \\
\text { the TWRS life cycle. }\end{array}$ \\
\hline $\begin{array}{l}425.1 \text { Core Requirement (17) - Adequacy of } \\
\text { Contractor Operational Readiness Review }\end{array}$ & I & $\begin{array}{l}\text { 2.3.6.-establishes required technical } \\
\text { reviews including ROD imposed Phase } 1 \\
\text { Operational Readiness Assessment. }\end{array}$ \\
\hline \begin{tabular}{|l|} 
D.1 Detailed Instructions for Assessment of RTP \\
- Appendix C, November 14,1997 \\
\end{tabular} & . & \\
\hline $\begin{array}{l}\text { 28. Describe the PHMC Team's systems engineering } \\
\text { regarding the ability to support private contractors. }\end{array}$ & I & $\begin{array}{l}\text { 2.3.2-establishes requirement to manage } \\
\text { interfaces including those with the } \\
\text { private contractors; 3.2.8-establishes } \\
\text { process for analyzing interfaces. }\end{array}$ \\
\hline
\end{tabular}


Table A-1. Guidance and Requirements to Deliverables Crosswalk TWRS System Engineering Management Plan.

\begin{tabular}{|c|c|c|}
\hline \multirow{2}{*}{$\begin{array}{l}\text { Guidance or Requirement } \\
\text { D.2 Plan for Determining PHMC-Team's RTP } \\
\text { for Waste Feed Delivery (Table 2). }\end{array}$} & \multirow[t]{2}{*}{ Status } & \multirow[t]{2}{*}{ Implementing Location } \\
\hline & & \\
\hline $\begin{array}{l}\text { PHMC provide deliverables necessary to support } \\
\text { RTP, as follows: }\end{array}$ & . & $\because$ \\
\hline 3. TWD SEMP & I & $\begin{array}{l}\text { TWD SE is contained in the TWRS } \\
\text { SEMP. Further implementation } \\
\text { description may be documented in } \\
\text { lower-level implementation plans, as } \\
\text { required. }\end{array}$ \\
\hline 21. Draft Alternative Generation Assessments & I & $\begin{array}{l}\text { 3.2.6-identifies process for "Alternative } \\
\text { Analysis and Selection" }\end{array}$ \\
\hline $\begin{array}{l}\text { 30. (Alternatives study) Best Basis/Inventory } \\
\text { Estimate AX Farms Ancillary Equipment }\end{array}$ & I & $\begin{array}{l}\text { 3.2.6-identifies process for "Alternative } \\
\text { Analysis and Selection" }\end{array}$ \\
\hline 38. PHMC Team Decision Support Documentation & I & $\begin{array}{l}\text { 2.3.4-establishes requirement to manage } \\
\text { and document the decision process; } \\
\text { 3.2.6-identifies the process for analyzing } \\
\text { alternatives and invoking the decision- } \\
\text { making process to select the "best" } \\
\text { alternative. }\end{array}$ \\
\hline $\begin{array}{l}\text { D.3 Plan for Determining PHMC-Team's RTP } \\
\text { for Waste Feed Delivery - Document Cheeklist } \\
\text { (Table 3) }\end{array}$ & : & $\therefore$ \\
\hline $\begin{array}{l}\text { 42. Plans describe PHMC's M\&I activities for the } \\
\text { PHMC Tank Waste Division, incl. program mgmt, } \\
\text { EM-30/50 int sppt, PBS program logic/WBS, int } \\
\text { with Hanford Mast Baseline Schedule, dev. of risk } \\
\text { dec. mgmt program, PHMC Program Plan, Sys Eng } \\
\text { Int Plan, QAPP, \& Part B App sppt. }\end{array}$ & I & $\begin{array}{l}\text { 2.x- This section of the SEMP outlines } \\
\text { the requirements to use disciplined } \\
\text { management processes to manage and } \\
\text { control the integrated baseline } \\
\text { throughout the life cycle. }\end{array}$ \\
\hline $\begin{array}{l}\text { 43. Plans describe defining feed process \& retrieval } \\
\text { system using systems engineering. }\end{array}$ & $\mathrm{I}$ & $\begin{array}{l}\text { 3.x-establishes process for establishing } \\
\text { requirements, selecting alternative } \\
\text { approaches, assessing alternatives, and } \\
\text { deciding on the "best solution to meet } \\
\text { mission objectives. }\end{array}$ \\
\hline $\begin{array}{l}\text { 45. Plans define retrieval project requirements to } \\
\text { interface w/ Hanford Tanks Initiative (HTI) \& other } \\
\text { EM-50 funded technology development projects. }\end{array}$ & I & $\begin{array}{l}\text { 2.3.2-establishes requirement to manage } \\
\text { interface at all levels of TWRS; } 3.2 .8 \text { - } \\
\text { establishes process to analyze interfaces. }\end{array}$ \\
\hline
\end{tabular}


Table A-1. Guidance and Requirements to Deliverables Crossivalk TWRS System Engineering Management Plan.

\begin{tabular}{|c|c|c|}
\hline Guidance or Requirement & Status & Implementing Location \\
\hline $\begin{array}{l}\text { 46. Plans describe completion of planning for tank- } \\
\text { 106 Heel removal using ACTR-defined technology. }\end{array}$ & I & $\begin{array}{l}\text { Figure 2-illustrates the development of } \\
\text { the integrated baseline and } \\
\text { implementation plans and procedures to } \\
\text { develop, in a hierarchical process, all the } \\
\text { systems, structures and components to } \\
\text { meet the mission objectives. HTI } \\
\text { elements are a part of this hierarchy. }\end{array}$ \\
\hline $\begin{array}{l}\text { 52. Plans include performance of Alternative } \\
\text { Generation Analyses and testing integral to the } \\
\text { Waste Ops and Utilization Plan. }\end{array}$ & $\mathrm{I}$ & $\begin{array}{l}\text { 3.2.6-identifies the process to evaluate } \\
\text { alternatives; } 3.5 \text {-establishes the } \\
\text { requirement to perform necessary test } \\
\text { and evaluation to ensure systems meet } \\
\text { requirements. }\end{array}$ \\
\hline $\begin{array}{l}\text { 56. Plans include resolving feed } \\
\text { delivery/composition issues identified by the } \\
\text { IP/Process Teams during development of the feed } \\
\text { ICDs and specs. }\end{array}$ & I & $\begin{array}{l}\text { 3.2. } x \text {-the process described in these } \\
\text { sections and procedures and references. } \\
\text { invoked describe the process for } \\
\text { resolving issues via a disciplined and } \\
\text { traceable process. }\end{array}$ \\
\hline $\begin{array}{l}\text { 57. Plans include performing alternative analyses } \\
\text { needed to support the ATP decision and TWRS } \\
\text { Program review per EIS ROD. } \\
\end{array}$ & I & $\begin{array}{l}\text { 3.2.6-identifies the process to evaluate } \\
\text { alternatives; } 2.3 .6 \text {-identifies reviews } \\
\text { required by the ROD. }\end{array}$ \\
\hline $\begin{array}{l}\text { 59. Plans describe evaluation of the sludge-washing } \\
\text { procest as required by TPA M-50-03 (Completed). }\end{array}$ & $I$ & $\begin{array}{l}\text { 3.2.6-identifies the process to evaluate } \\
\text { alternatives; } 3.5 \text {-establishes the } \\
\text { requirement to perform necessary test } \\
\text { and evaluation to ensure systems meet } \\
\text { requirements. }\end{array}$ \\
\hline $\begin{array}{l}\text { 65. Plans include completing design activities and } \\
\text { safety studies to support installation of the mixer } \\
\text { pumps in AP-102, } 104 \text { and } 105 \text { and determine the } \\
\text { needs for all tanks identified in the Phase } 1 \text { feed. }\end{array}$ & I & $\begin{array}{l}\text { 3.2.6-identifies the process to evaluate } \\
\text { alternatives. }\end{array}$ \\
\hline $\begin{array}{l}\text { 69. Plans include formulating the basis and continue } \\
\text { to develop/demonstrate the best retrieval methods } \\
\text { from industry \& DOE Complex to suppoit closure } \\
\text { prep of C-106 \& AX-104 as part of HTI. }\end{array}$ & I & $\begin{array}{l}\text { 3.2.6-identifies the process to evaluate } \\
\text { alternatives; } 3.5 \text {-establishes the } \\
\text { requirement to perform necessary test } \\
\text { and evaluation to ensure systems meet } \\
\text { requirements. }\end{array}$ \\
\hline
\end{tabular}


Table A-1. Guidance and Requirements to Deliverables Crosswalk TWRS System Engineering Management Plan.

\begin{tabular}{|c|c|c|}
\hline Guidance or Requirement & Status & Implementing Location \\
\hline $\begin{array}{l}\text { D.4 PHMC RTP; Approach for the Evaluation of } \\
\text { Administrative Readiness, December } 4,1997\end{array}$ & . & . \\
\hline $\begin{array}{l}\text { 21. Systems Engineering - SE is the PHMC Team's } \\
\text { way of doing business. There is management } \\
\text { sponsorship, worker ownership, and continuous } \\
\text { improvement. }\end{array}$ & I & $\begin{array}{l}\text { SEMP; 2.2.2-establishes intent to assess } \\
\text { maturity of SE in TWRS as a means of } \\
\text { continuous improvement. }\end{array}$ \\
\hline $\begin{array}{l}\text { D.6 Draft Plan for Determining RTP for } \\
\text { Infrastructure \& Byproducts Delivery, Appendix } \\
\text { A, Technical Baseline Checklist. }\end{array}$ & 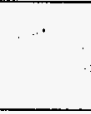 & \\
\hline $\begin{array}{l}\text { 10. Provide (on request) an Infrastructure SEMP } \\
\text { based on the TWRS SEMP. (2.2.1) }\end{array}$ & I & $\begin{array}{l}\text { The TWRS SEMP will be the only } \\
\text { SEMP for the program. Lower level } \\
\text { implementation plans may be developed } \\
\text { if deemed necessary. }\end{array}$ \\
\hline $\begin{array}{l}\text { 24. Provide complete Alternatives Generations } \\
\text { Analyses (AGAs) with checklists and decision } \\
\text { process checklists. }(6.3 .1-6.3 .3)\end{array}$ & I & $\begin{array}{l}\text { 2.3.4-establishes requirement to manage } \\
\text { and document the decision process; } \\
\text { 3.2.6-identifies the process for analyzing } \\
\text { alternatives and invoking the decision- } \\
\text { making process to select the "best" } \\
\text { alternative. }\end{array}$ \\
\hline $\begin{array}{l}\text { 25. Provide the completed quantitative } \\
\text { reliability/availability/maintainability analysis. } \\
(6.4 .1)^{3}\end{array}$ & $\mathrm{I}$ & $\begin{array}{l}\text { 3.2.2- identifies process for establishing } \\
\text { the O\&M concept which forms the basis } \\
\text { for RAM analysis; } 3.2 .3,4 \text {-identifies the } \\
\text { process for establishing functional and } \\
\text { performance requirements, including } \\
\text { RAM; } 3.2 .5 \text {-identifies the process for } \\
\text { assessing alternatives (including existing } \\
\text { systems) }\end{array}$ \\
\hline $\begin{array}{l}\text { 26. Provide the risk/benefit analysis and identify } \\
\text { risks on risk list. }(6 \cdot 4 \cdot 2-6.4 .3)\end{array}$ & I & $\begin{array}{l}\text { 2.3.3-establishes the requirement for risk } \\
\text { management and refers to the Risk } \\
\text { Management Plan which includes the } \\
\text { establishment of risk lists; } 3.2 .6- \\
\text { establishes risk as a parameter to be } \\
\text { considered in evaluation and selection of } \\
\text { design alternatives. }\end{array}$ \\
\hline
\end{tabular}


Table A-1. Guidance and Requirements to Deliverables Crosswalk TWRS System Engineering Management Plan.

\begin{tabular}{|l|}
\hline \multicolumn{2}{|c|}{ Guidance or Requirement } \\
\hline D.8 Draft Plan for Determining RTP for \\
Infrastructure \& Byproducts Delivery, Appendix \\
C, Infrastructure (Management Baseline) \\
Checklist.
\end{tabular}

42. Confirm the Project and SEMP execution plans are to be developed. $(1.2 .4 ; 1.2 .7)$

49. Show that the risk and decision management program is acceptable or is not needed. (1.5.1)

\section{D.9 Draft Plan for Determining RTP for} Infrastructure \& Byproducts Delivery, Appendix D, Feed Tank/Air Emissions (Technical Baseline Cbecklist).

68. Provide complete Alternatives Generations Analyses (AGAs) with checklists and decision. process checklists. (6.3.1-6.3.3)

70. Provide the risk/benefit analysis and identify risks on risk list. (6.4.2-6.4.3)

\begin{tabular}{|l|l|}
\hline Status & Implementing Location \\
\hline
\end{tabular}

\begin{tabular}{|c|c|c|}
\hline process checklists. $(6.3 .1-6.3 .3)$ & & $\begin{array}{l}\text { 3.2.6-identifies the process for analyzing } \\
\text { alternatives and invoking the decision- } \\
\text { making process to select the "best" } \\
\text { alternative. }\end{array}$ \\
\hline $\begin{array}{l}\text { 70. Provide the risk/benefit analysis and identify } \\
\text { risks on risk list. (6.4.2-6.4.3) }\end{array}$ & $\mathrm{I}$ & $\begin{array}{l}\text { 2.3.3-establishes the requirement for risk } \\
\text { management and refers to the Risk } \\
\text { Management Plan which includes the } \\
\text { establishment of risk lists; } 3.2 .6 \text { - } \\
\text { establishes risk as a parameter to be } \\
\text { considered in evaluation and selection of } \\
\text { design alternatives. }\end{array}$ \\
\hline $\begin{array}{l}\text { D.11 Draft Plan for Determining RTP for } \\
\text { Infrastructure \& Byproducts Delivery, Appendix } \\
\text { E, Infrastructure Feed Tank Transfer } \\
\text { (Management Baseline) Checklist. }\end{array}$ & . & \\
\hline $\begin{array}{l}\text { 86. Confirm the Project and SEMP execution plans } \\
\text { are to be developed. }(1.2 .4 ; 1.2 .7)\end{array}$ & I & $\begin{array}{l}\text { The TWRS Retrieval and Disposal } \\
\text { Mission Initial Updated Baseline (HNF- } \\
\text { 1946) reflects the execution of planned } \\
\text { work including SEMP derived tasks. }\end{array}$ \\
\hline
\end{tabular}


HNF-SD-WM-SEMP-002 Rev 1

Table A-1. Guidance and Requirements to Deliverables Crosswalk TWRS System Engineering Management Plan.

\begin{tabular}{|l|c|l|}
\hline \multicolumn{1}{|c|}{ Guidance or Requirement } & Status & \multicolumn{1}{|c|}{ Implementing Location } \\
\hline $\begin{array}{l}\text { 9j. Show that the risk and decision management } \\
\text { program is acceptable or is not needed. (1.5.1) }\end{array}$ & I & $\begin{array}{l}\text { 2.3.3-establishes the requirement to } \\
\text { manage risks; 2.3.4-establishes the } \\
\text { requirement to manage decisions. }\end{array}$ \\
\hline $\begin{array}{l}\text { E.1 TWRS Waste Disposal Division Planning } \\
\text { Guidance dated July 7, 1997 (Updated December } \\
\text { 12, 1997) }\end{array}$ & . & \\
\hline $\begin{array}{l}\text { Project plan for management, administrative, and } \\
\text { system definition of projects WIT plan for support to } \\
\text { WDD. }\end{array}$ & I & $\begin{array}{l}\text { 3.2.x-defines the process for "system } \\
\text { definition". }\end{array}$ \\
\hline $\begin{array}{l}\text { Cesium and Strontium Capsules project will update } \\
\text { the Alternative Generation Analysis and Decision } \\
\text { Analysis Report and the Cesium Strontium Capsule } \\
\text { Disposition Decision Analysis. }\end{array}$ & I & $\begin{array}{l}\text { l.1-establishes the applicability of the } \\
\text { SEMP for TWRS contractor which } \\
\text { includes "projects"; 3.2.x-defines } \\
\text { process for establishing technical } \\
\text { baseline, including performing necessary } \\
\text { "alternative analyses". }\end{array}$ \\
\hline $\begin{array}{l}\text { The Retrieval MYWP will provide top-level, } \\
\text { technical logic, technical requirements, and } \\
\text { associated interrelationships to define the total } \\
\text { Retrieval work scope. } \\
\vdots\end{array}$ & I & $\begin{array}{l}\text { Figure 2 indicates the technical baseline } \\
\text { (e.g., requirements and interfaces) is an } \\
\text { primary input into the integrated baseline } \\
\text { and subsequent MYWP development } \\
\text { process. }\end{array}$ \\
\hline
\end{tabular}


HNF-SD-WM-SEMP-002 Rev 1

This page intentionally left blank. 
HNF-SD-WML-SEMP-002 Rev 1

\author{
APPENDIX B \\ COMPLIANCE MATRIX OF \\ TANK WASTE REMEDIATION SYSTEM \\ SYSTEMS ENGINEERING MANAGEMENT PLAN \\ TO THE U.S. DEPARTMENT OF ENERGY, \\ RICHLAND OPERATIONS OFFICE \\ TANK WASTE REMEDIATION SYSTEM \\ SYSTEMS ENGINEERING MANAGEMENT POLICY
}


HNF-SD-WM-SEMP-002 Rev 1

This page intentionally left blank. 


\section{Compliance Matrix of Tank Waste Remediation System Systems Engineering Management Plan to the U.S. Department of Energy, Richland Operations Office Tank Waste Remediation System Systems Engineering Management Policy}

\begin{tabular}{|c|c|c|}
\hline Policy Element & TWRS Implementation & $\begin{array}{l}\text { Location in } \\
\text { SEMP : }\end{array}$ \\
\hline $\begin{array}{l}\text { 2.A Systems engineering shall be applied throughout the } \\
\text { system life cycle as a comprehensive, iterative technical } \\
\text { management process to: } \\
\text { 1. Translate a need into a configured system } \\
\text { meeting that need through a systematic approach } \\
\text { that integrates the development, construction, test, } \\
\text { operations, support, and decommissioning of the } \\
\text { system; }\end{array}$ & $\begin{array}{l}\text { The system life cycle described in DOE Order } 430.1 \\
\text { is implemented by this SEMP. The template for } \\
\text { Systems Engineering in Good Practice Guide (GPG) } \\
\text { GPG-FM-010, Project Execution and Engineering } \\
\text { Management Planning, is used as the guide to } \\
\text { implement a life cycle approach to systems } \\
\text { cngineering. }\end{array}$ & $\begin{array}{l}1.0 \\
1.2 \\
2 . X \\
3 . X\end{array}$ \\
\hline $\begin{array}{l}\text { 2. Integrate the technical inputs and necessary } \\
\text { technical disciplines into a coordinated effort that } \\
\text { meets established program cost, schedule, and } \\
\text { performance objectives; }\end{array}$ & $\begin{array}{l}\text { TWRS will identify personnel with the necessary } \\
\text { technical background and experience to ensurc } \\
\text { timely incorporation of their expertise into the } \\
\text { planning, development, and design process as } \\
\text { applicable. }\end{array}$ & $\begin{array}{l}3.2 .9 \\
3.2 .11 \\
3.7\end{array}$ \\
\hline $\begin{array}{l}\text { 3. Ensure the compatibility of functional and } \\
\text { physical interfaces (internal and external) }\end{array}$ & $\begin{array}{l}\text { Interfaces will be developed and controlled through } \\
\text { a documented and disciplined process. Interface } \\
\text { Control Documents will be developed as a } \\
\text { management tool to control the configuration of } \\
\text { interfaces. }\end{array}$ & $\begin{array}{l}2.3 .2 \\
3.2 .8\end{array}$ \\
\hline
\end{tabular}




\begin{tabular}{|c|c|c|}
\hline Policy Element & TWRS Implementation & $\begin{array}{l}\text { Location in } \\
\text { SEMP }\end{array}$ \\
\hline $\begin{array}{l}\text { 4. Ensure that system definition and design reflect } \\
\text { the requircments of the system clements (e.g. } \\
\text { hardware, software, facilities, personnel, and data); }\end{array}$ & $\begin{array}{l}\text { The system definition process outlined in DOE } \\
\text { Order } 430.1 \text { GPG-FM-010 will be used to define } \\
\text { and design system elements. }\end{array}$ & $\begin{array}{l}3.2 .1 \\
3.2 .2 \\
3.4 \\
3.2 .5 \\
3.2 .6 \\
3.3 \\
3.4 \\
3.5\end{array}$ \\
\hline $\begin{array}{l}\text { 5. Characterize risks, develop risk abatement } \\
\text { approaches, and manage the risk cost effectively }\end{array}$ & $\begin{array}{l}\text { A disciplined process of assessing, handling, and } \\
\text { mitigating technical and programmatic risks will be } \\
\text { used. }\end{array}$ & $\begin{array}{l}2.3 .3 \\
3.2 .6 \\
3.2 .11\end{array}$ \\
\hline 3.A Systems Engineering Tasks & $\because$ & \\
\hline 3.A.1 Translate need into system design & $\because$ & \\
\hline $\begin{array}{l}\text { 3.^.1.a Use a disciplined requirements collection and } \\
\text { translation methodology to convert requirements into } \\
\text { design specifications. }\end{array}$ & $\begin{array}{l}\text { TWRS will use the systems engineering process } \\
\text { outlined in DOE Order } 430.1 \text { GPG-FM-010 to } \\
\text { develop design-to specification. The Hanford Site } \\
\text { Technical Database (RDD-100) will be used as the } \\
\text { database system for requirements traceability. }\end{array}$ & $\begin{array}{l}3.2 .3 \\
3.2 .4 \\
3.2 .7 \\
3.2 .10 \\
2.3 .5\end{array}$ \\
\hline $\begin{array}{l}\text { 3.A.1.b Establish a process which balances the } \\
\text { development of specifications, the conduct of trade-offs of } \\
\text { allernative concepts, and the establishment of a cost } \\
\text { effective system design. }\end{array}$ & $\begin{array}{l}\text { The systems engineering process will be } \\
\text { implemented to meet this expectation. }\end{array}$ & $3 . \mathrm{X}$ \\
\hline $\begin{array}{l}\text { 3.A.2 Integrate the system. Develop and document } \\
\text { agrecments where two or more entities functionally or } \\
\text { physically connect. }\end{array}$ & $\begin{array}{l}\text { TWRS will document and control interfaces } \\
\text { betwcen elements of the program. }\end{array}$ & $\begin{array}{l}2.3 .2 \\
3.2 .8\end{array}$ \\
\hline
\end{tabular}




\begin{tabular}{|c|c|c|}
\hline Policy Element & TWRS Implementation & $\begin{array}{l}\text { Location in } \\
\text { SEMP }\end{array}$ \\
\hline $\begin{array}{l}\text { 3.A.3 Adapt existing/emerging technology to meet } \\
\text { program-specific needs }\end{array}$ & $\begin{array}{l}\text { As part of the alternative evaluation process, } \\
\text { new/cmerging technology will be assessed to } \\
\text { determine its applicability to meeting the TWRS } \\
\text { mission. }\end{array}$ & $\begin{array}{l}3.2 .6 \\
3.2 .11 \\
3.5\end{array}$ \\
\hline $\begin{array}{l}\text { 3.A.3.b Define transition criteria and implementation } \\
\text { methodology prior to the transition of the technology into } \\
\text { engineering development. }\end{array}$ & $\begin{array}{l}\text { In cases where risks of implementation of a } \\
\text { technology are high, testing may be required to } \\
\text { reduce risk and to establish the design parameters } \\
\text { and select from available technology. }\end{array}$ & $\begin{array}{l}3.2 .6 \\
3.5\end{array}$ \\
\hline $\begin{array}{l}\text { 3. A.4.a Identify, assess, and communicate technical and } \\
\text { programmatic risks throughout the program life cycle. }\end{array}$ & Sec above. & 2.3 .3 \\
\hline $\begin{array}{l}\text { 3.A.4.b Establish a risk management strategy that includes } \\
\text { provisions for climinating or reducing risks to acceptable } \\
\text { levels. }\end{array}$ & See above. & 2.3 .3 \\
\hline $\begin{array}{l}\text { 3. } \Lambda \text {. } 4 \text {. } \Lambda \text { decision points, assess the impacts of risk on } \\
\text { program cost, schedule, and technical performance, effects } \\
\text { of risk mitigation efforts, rationale and assumptions made in } \\
\text { assigning risk ratings. }\end{array}$ & See above. & $\begin{array}{l}2.3 .3 \\
2.3 .4 \\
2.3 .6\end{array}$ \\
\hline
\end{tabular}




\begin{tabular}{|c|c|c|}
\hline Policy Element & TWRS Implementation & $\begin{array}{l}\text { Location in } \\
\text { SEMP }\end{array}$ \\
\hline $\begin{array}{l}3 . \Lambda .5 \text { Verify that the system design meets the need. } \\
\text { Verification is the process of ensuring that the } \\
\text { requirements meets system objectives. }\end{array}$ & $\begin{array}{l}\text { TWRS will establish a test and evaluation strategy } \\
\text { and implement test and evaluation as applicable as a } \\
\text { life-cycle process to ensure the TWRS system meets } \\
\text { requirements. }\end{array}$ & $\begin{array}{l}3.5 \\
3.2 .5\end{array}$ \\
\hline $\begin{array}{l}\text { 3. A.5.a Establish a comprehcnsive process to integrate } \\
\text { design analysis, design simulation, demonstration and test to } \\
\text { verify that the selected design meets program needs. Design } \\
\text { analysis and simelation supplement demonstration and } \\
\text { testing. Where total system verification by test is not } \\
\text { appropriate, testing wilt be used to verify key characteristics } \\
\text { and assumptions used in the design analysis or simulation. }\end{array}$ & $\begin{array}{l}\text { A test and evaluation program will be established } \\
\text { that incorporates analysis, simulation, } \\
\text { demonstration, test, and inspection in a cost- } \\
\text { effective manner to verify the TWRS system meets } \\
\text { program needs. }\end{array}$ & 3.5 \\
\hline $\begin{array}{l}\text { 3. A.5.b Identify critical design characteristics and verify } \\
\text { through demonstration and/or test. }\end{array}$ & See above. & $\begin{array}{l}3.5 \\
2.3 .7\end{array}$ \\
\hline $\begin{array}{l}\text { 3.A.5.c Track and monitor the progress of system's } \\
\text { maturity to ensure that requirements are met prior to } \\
\text { system's procurement and operations. }\end{array}$ & $\begin{array}{l}\text { Technical performance measures (i.c., Technical } \\
\text { Performance Measurement) will be established and } \\
\text { tacked to assess progress toward meeting technical } \\
\text { objectives. }\end{array}$ & $\begin{array}{l}2.3 .7 \\
3.5\end{array}$ \\
\hline $\begin{array}{l}\text { 3.B Systems Engineering Management } \\
\text { An effective systems engineering management program will } \\
\text { be implemented. Reviews will be conducted periodically to } \\
\text { assess the progress of the effort and the risk in the design. } \\
\text { Establish a comprehensive plamming and control system for } \\
\text { systems cngineering management. This system will include } \\
\text { engineering planning, technical data management, work } \\
\text { breakdown structure, configuration management, technical } \\
\text { perlormance meisurement, and cost/schedule control } \\
\text { system. }\end{array}$ & $\begin{array}{l}\text { System engineering management principles will be } \\
\text { implemented to assure adequate oversight and } \\
\text { control of the TWRS program planning, design } \\
\text { development, design implementation, and operation } \\
\text { of the TWRS system. These principles include } \\
\text { risk/decision management, configuration } \\
\text { management, interface control, technical revicws, } \\
\text { and quality assurance. }\end{array}$ & All $2 . X$ \\
\hline
\end{tabular}




\begin{tabular}{|c|c|c|}
\hline Policy EIenent & $\because \quad \begin{array}{l}\text { TWRS Implementation } \\
\cdots\end{array}$ & $\begin{array}{l}\text { Location in } \\
\text { SEMP }\end{array}$ \\
\hline 3.B.1 Planning & & \\
\hline $\begin{array}{l}\text { 3.B.1.a Systems Engineering Management Plan. } \\
\text { Develop a Systems Engineering Management Plan which } \\
\text { implements this policy. The Systems Engineering } \\
\text { Manngement Plan describes the following: } \\
\text { 1) Systems enginecring process }\end{array}$ & $\begin{array}{l}\text { A TWRS SEMP will be developed to express the } \\
\text { plan for meeting system engincering policy } \\
\text { expectations. } \\
\text { The system engineering process will be described } \\
\text { that is consistent with DOE Order } 430.1 \text {. }\end{array}$ & $\begin{array}{l}\text { SEMP } \\
\text { - Entire document } \\
3 x\end{array}$ \\
\hline $\begin{array}{l}\text { 2) Systems engineering management approach } \\
\text { a) Performance measures development and } \\
\text { reporting }\end{array}$ & $\begin{array}{l}\text { A process for cstablishing and tracking technical } \\
\text { performance measures will be ontlined in the SEMP } \\
\text { with reference to related guidance. }\end{array}$ & $\begin{array}{l}2.3 .7 \\
3.5\end{array}$ \\
\hline $\begin{array}{l}\text { b) Key engineering milestones, schedules } \\
\text { and reviervs }\end{array}$ & $\begin{array}{l}\text { Appropriate references to documents containing key } \\
\text { milestones and schedules will be made. Primary } \\
\text { technical reviews will be identified in the SEMP. }\end{array}$ & $\begin{array}{l}2.1 \\
2.3 .6\end{array}$ \\
\hline $\begin{array}{l}\text { c) Organization and key personnel for } \\
\text { program managenent; responsibilities and } \\
\text { lines of communication for the } \\
\text { implementation of systems engineering } \\
\text { policy. }\end{array}$ & $\begin{array}{l}\text { Appropriate references to documents containing } \\
\text { organization and program management guidance } \\
\text { will be made. Primary responsibilities for system } \\
\text { enginecring products will be identified in the SEMP. }\end{array}$ & $\begin{array}{l}1.3 \text { - Refers to } \\
\text { TWRS Program } \\
\text { Plan } \\
3.6- \\
\text { Responsibilitics } \\
\text { Cor Sl: Products }\end{array}$ \\
\hline
\end{tabular}




\begin{tabular}{|c|c|c|}
\hline Policy Element & TWRS Implementation & $\begin{array}{l}\text { Location in } \\
\text { SEMP }\end{array}$ \\
\hline 3) Integration of the required technical specialties & $\begin{array}{l}\text { Integration of technical specialties is part of the } \\
\text { basic system engineering process described in the } \\
\text { SEMP. The SEMP also references the Tank Waste. } \\
\text { Remediation System Engineering Plan } \\
\text { (Rifaey 1998). }\end{array}$ & $\begin{array}{l}3.2 .11 \\
3.2 .9 \\
3.7\end{array}$ \\
\hline 4) System integration strategy. & $\begin{array}{l}\text { Program integration via the technical baseline, } \\
\text { progran logics, schedules, and cost are defined in } \\
\text { the SEMP. } \\
\text { Technical integration is a product of the application } \\
\text { of the systems engineering process described in the } \\
\text { SEMP. }\end{array}$ & 3.1 \\
\hline $\begin{array}{l}\text { 3.B.1.b Technical Data Managenent. } \\
\text { Develop and ensure avaitabijity of defensible technical data. } \\
\text { 1) Lnsure that the appropriate level of design detail } \\
\text { is formally documented. Design data start as mission } \\
\text { needs which become system requirements throngh } \\
\text { appropriate analysis. System requirements are } \\
\text { translated to determine detailed design requirements } \\
\text { which evolve into specifications, drawings, process } \\
\text { specifications, and procedures. }\end{array}$ & $\begin{array}{l}\text { The HSTD (RDD-100) will be identified as the } \\
\text { means of maintaining a traccable flow of } \\
\text { requirements from the Hanford Site level through } \\
\text { the TWRS mission analysis, to Level } 1 \text { facility } \\
\text { specifications, to Level } 2 \text { design-to specifications. } \\
\text { The Tank Waste Remedicuion System Configuration } \\
\text { Management Plan (Vann et al. 1998) is referenced } \\
\text { in the SEMP and defines control of the technical } \\
\text { baseline documentation. }\end{array}$ & $\begin{array}{l}2.3 .5 \\
3.2 .1 \\
3.2 .3 \\
3.2 .4 \\
3.2 .7 \\
3.2 .10 \\
3.3 \\
3.4 \text { (see } \\
\text { Engineering Plan) } \\
3.6 \\
2.3 .1\end{array}$ \\
\hline $\begin{array}{l}\text { 2) Ensure that necessary supporting documentation } \\
\text { (e.g. design analysis reports, trade studies, and test } \\
\text { reports) ate developed and recorded to provide } \\
\text { traceability of system design to program needs. }\end{array}$ & $\begin{array}{l}\text { The SEMP will indicate that the HSTD will contain } \\
\text { and/or refer to necessary supporting documentation. }\end{array}$ & $\begin{array}{l}2.3 .5 \\
2.3 .1\end{array}$ \\
\hline
\end{tabular}




\begin{tabular}{|c|c|c|}
\hline Policy Element & - TWRS Implementation & $\begin{array}{l}\text { Location in } \\
\text { SEMP }\end{array}$ \\
\hline $\begin{array}{l}\text { 3) Ensure that all pertinent data is available to users } \\
\text { and customers of the system. }\end{array}$ & $\begin{array}{l}\text { Documents referred to will be identifiable and } \\
\text { accessible to users and customers in accordance } \\
\text { with company policy. }\end{array}$ & $\begin{array}{l}2.3 .5 \\
2.3 .1\end{array}$ \\
\hline $\begin{array}{l}\text { 3.B. 1.c Work Breakdown Structure. } \\
\text { Develop a work breakdown structure (WBS) that provides } \\
\text { the framework relating and controlling work products and } \\
\text { services which comprise the work effort. The WBS should } \\
\text { be capable of relating system clements to applicable } \\
\text { teclunical and management reports, hardware, software and } \\
\text { data elements of the sysiem. The WBS shoull be developed } \\
\text { so that it provides the association between the cfforts needed } \\
\text { to devclop the system and the life-cycle costs accrued in } \\
\text { performing the efforts. }\end{array}$ & $\begin{array}{l}\text { Reference to applicable documents containing } \\
\text { guidance and direction on development of the } \\
\text { TWRS Work Breakdown Structure will be made. }\end{array}$ & $\begin{array}{l}2.1 \\
3.3\end{array}$ \\
\hline \multicolumn{3}{|l|}{ 3.B.2 Control } \\
\hline $\begin{array}{l}\text { 3.B.2.a Configuration Management } \\
\text { Contiguration Management is to be used to identify products } \\
\text { and basclines (systems, structures, components, documents, } \\
\text { waste inveintorics, ctc.) to be controlled and to manage } \\
\text { selected important product information throughout the } \\
\text { product's life cycle. Consistency will be maintained among } \\
\text { requirements, products, and product information. Decision } \\
\text { bases will be traccable and retrievable. Application of } \\
\text { configuration management principles will ensure that } \\
\text { accurate information is available in a timely manner and that } \\
\text { the program adheres to a methodical process of change } \\
\text { control. }\end{array}$ & $\begin{array}{l}\text { The SEMP will outline the plan for life-cycle } \\
\text { configuration management and refer to appropriate } \\
\text { guidance documents. }\end{array}$ & 2.3 .1 \\
\hline
\end{tabular}




\begin{tabular}{|c|c|c|}
\hline Policy Element & PWRS Implementation & $\begin{array}{l}\text { Location in } \\
\text { SEMP }\end{array}$ \\
\hline $\begin{array}{l}\text { 3.B.2.b Technical Performance Measurement } \\
\text { Develop and maintain a technical performance measurement } \\
\text { process to assess how well the evolving design satisfies the } \\
\text { system requirements. Systems requirements must be } \\
\text { converted into measures which arc meaningful, quantifiable } \\
\text { and capable of being used in the system's verification } \\
\text { process. } \\
\text { 1) The data for each measure will be based upon } \\
\text { engineering judgement, design analysis, and test } \\
\text { data, depending upon the status of the design. }\end{array}$ & $\begin{array}{l}\text { A technical performance measurement program will } \\
\text { be outlined with reference to guidance documents. }\end{array}$ & $\begin{array}{l}2.3 .7 \\
3.5\end{array}$ \\
\hline $\begin{array}{l}\text { 2) Particular attention will be paid to those measures } \\
\text { that are critical to management of high risk areas. }\end{array}$ & See above & $\begin{array}{l}2.3 .7 \\
2.3 .3\end{array}$ \\
\hline $\begin{array}{l}\text { 3.B.2.c Cost/Schedule Control System } \\
\text { Develop and maintain a system capable of tracking systems } \\
\text { development for current costs, life cycle costs, and } \\
\text { milestones tied to the WBS. }\end{array}$ & $\begin{array}{l}\text { Reference to appropriate TWRS documents will be } \\
\text { made. }\end{array}$ & 2.1 \\
\hline
\end{tabular}




\begin{tabular}{|c|c|c|}
\hline Policy Element $\quad$ P & TrWRS Implementation & $\begin{array}{l}\text { Location in } \\
\text { SEMP }\end{array}$ \\
\hline $\begin{array}{l}\text { 3.C Technical Discipline Integration } \\
\text { The development of complex systems requires the } \\
\text { integration of a variety of technical disciplines (e.g., } \\
\text { supportability, human systems integration, and health and } \\
\text { safety). Requirements for various technical specialiies will } \\
\text { vary depending upon the nature of the program. The systems } \\
\text { engineering process will allocate systems requirements to } \\
\text { establish clear technical requirements for each technical } \\
\text { specialty in a concurrent manner to support the integrated } \\
\text { system design. The systems engineering process will } \\
\text { collectively analyze the design specifications, conduct trade- } \\
\text { offs, balance total systems requirements, and establish the } \\
\text { linal conliguration. }\end{array}$ & $\begin{array}{l}\text { Reference to applicable TWRS documents } \\
\text { containing guidance on technical discipline } \\
\text { integration will be made. Specialty Engineering } \\
\text { disciplines are integrated via application of the SE } \\
\text { process and procedures (e.g., Level } 2 \text { specification } \\
\text { development procedure). }\end{array}$ & $\begin{array}{l}3.2 .9 \\
3.2 .10\end{array}$ \\
\hline
\end{tabular}

Sources: RL, 1997, Tank Waste Remediation System Systems: Engineering Management Policy, 97-MSD-193, U.S. Department of Energy, Riclıland Operations Oflice, Richland, Washington.

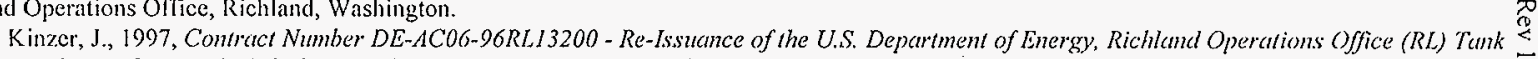
Waste Remedicuion System (7WRS) Systems Engineering Management Policy (letter 97-MSD-193 to H. J; Hatch, President, Fluor Daniel Hanford, Inc.) U.S. Department of Energy, Richland Operations Office, Richland, Washington.

DOE Order 430.1, Life Cycle Asset Mamagement, U.S. Department of Energy, Washington, D.C.

GPG-FM-010, Project Execution and Engineering Management Plaming, Life Cycle Asset Management, Good Practice Guide, U.S. Department of Energy, Washington, D.C.

HSTD, nd., Hanford Site Technical Baseline Database, database maintained by Lockhecd Martin Hanford Corporation for Fluor Daniel Hanford, Inc., Richland, Washington.

Rifaey, S. H., 1998, Tank Waste Remediation System Engineering I'lan, HNF-1947, Rev. 0, prepared by Lockheed Martin I lantord Corporation for Fluor Danicl Hanford, Inc., Richland, Washington.

Vann, J. M., E. R. Hamm, and R. D. Crisp, 1998, Tank Waste Remediation System Configuraton Manugemen I'lan, HNF-1900, Rev. 0, prepared by Lockheed Marlin Hanford Corporation for Fluor Daniel Hanford, Inc., Richland, Washington.
DOE = U.S. Department of Energy
$\mathrm{SEMP}=$ Systems Engineering Management Plan
TWRS $=$ Tank Waste Remediation System 
HNF-SD-WM-SEMP-002 Rev 1 